\title{
WFK 중장기 전략 수립을 위한 수원국 중심의 해외봉사단 성과 요소 분석
}

구영은 (KOICA 월드프렌즈총괄팀 전문관) 최경화 (KOICA 월드프렌즈총괄팀 전문관) 손성경 (서울대학교 국제대학원 국제지역학과 석사과정)

목차

I. 서론

II. 주요 개념 및 이슈

1. 해외봉사란

2. 해외봉사를 통해서 누가 혜택을 받는가

3. 봉사활동에 기술(skill)이 중요한가

4. 봉사활동 파견 기간이 중요한가

5. 봉사활동의 방향: 해외봉사단원을 누가 파견하며 누가 수원하는가

III. 해외봉사가 개발에 주는 성과 요소 및 분류

1. 해외봉사와 개발간 연계

2. 해외봉사의 성과 및 성관 분류체계 분석

N. 종합분석 및 결론

참고문헌 


\section{I. 서론}

우리나라 해외봉사사업은 1989 년부터 추진되기 시작하여 오늘날까지 점점 확대되었다. 타 선 진국에 비해 상대적으로 역사가 짧은 한국의 해외봉사단으로서, 한국의 해외봉사단의 위상이 최 근 몇 년 간 급부상한 것은 높이 평가할 만 하다고 할 수 있다. 특히 $\mathrm{KOICA}$ 의 월드프렌즈 해외 봉사단 파견사업(World Friends Korea, 이하 WFK)은 대표적인 국민참여형 협력 사업으로, 개 도국에 우리 국민을 파견하여 봉사활동을 통해 개도국의 빈곤감소와 지속가능한 발전을 지원하는 사업으로 인식되고 있다.1)

이 가운데 국제적으로 경제 불안정 추세가 고조되면서 개발사업의 각종 이해관계자로부터의 투 자 및 세금 지출의 효율성이 강조되고 있고, 해외봉사단 사업 규모의 크기와 발전 속도를 고려했 을 때, 해외봉사단의 객관적, 계량적 모니터링과 성과평가의 중요성도 점점 강조되는 추세다. 과 거에 해외봉사단 인원증가와 운영의 질에 상대적으로 치우쳤던 것에서 좀 더 나아가, 이제는 프 로그램의 성과와 질에 초점이 맞추어지는 추세라 할 수 있다.

본문에서 자세히 다루겠지만, 해외봉사단이 어떠한 요소와 프로세스를 통해 그 궁극적 목적인 개발성과를 보다 잘 달성할 수 있는지가 전세계 해외봉사단 파견기관의 주요 의제가 되고 있다. 특히, 성과 요소 파악을 통한 성과 분류 및 측정방안 (지표 포함) 수립은 성과평가 체계 구축 이 전에 탄탄히 기획되어야 하는 사안이라 할 수 있다. 즉, 해외봉사단의 어떠한 요소 및 프로세스가 어떠한 부문에서 효과를 극대화 시킬 수 있는지에 대한 적절하며 충분한 검토가 이루어지고, 이 러한 요소를 측정할 수 있는 방안 (지표 수립, 지표별 성과측정법 등)이 마련되어야, 어떠한 이해 관계자라도 (예: 정부, 봉사단 관계자 등) 납득할만한 성과평가가 이루어질 수 있는 것이다. 그럼 에도 불구하고, 한국 해외봉사단은 객관적으로 납득할만한 성과 요소 및 지표를 보유하고 있지 않다. 이는 성과평가를 어렵게 하는 요인이 되고 있다.

한편, 현재까지 해외봉사단의 성과관리 체계에 있어서 전 세계가 동의하는 합의점이 도출되지 않은 것은 사실이라 할 수 있다. 대부분의 해외봉사단이 봉사단 파견의 목적을 개발성과 달성에 두었다 해도 (자세한 내용은 본문 참조), 세부 목표 및 요소와 전략이 제각기 다르기 때문이다. 예를 들어, 정부로부터 경영실적을 평가받아야 하는 WFK 사업은 정부가 개입하지 않는 영국의 Voluntary Service Overseas (VSO)와는 성과평가 및 성과요소의 우선순위에 있어서 차이가 날 수 밖에 없다. 해외봉사단의 실적을 평가하는 이해관계자가 다르기 때문이다. 이러한 차이점은 해 외봉사단 성과측정을 위한 범세계적인 공통 성과모델 및 지표의 도출을 어렵게 하는 요인이기도

1) KOICA (2016) 이사장 ODA 기본 동향 보고자료 : 사업세션 (내부자료). p.6. 성남: 한국국제협력단 기획조정팀 
하다. 더불어, 해외봉사단 성과측정 분야 자체가 최근 몇 년 사이에 논의되기 시작한 주제이기 때 문에, 타국 해외봉사단들도 자체적인 틀이나 구체적 체계를 확립한 사례가 적다는 문제도 있다. 즉, 해외봉사단의 성과와 관련한 통일된 요소 및 방법론에 대해 그 어떤 해외봉사단도 이렇다 할 만한 모델을 제시하고 있지 못하는 상황이다. 때문에 현재로서는 해외봉사단의 측정 가능한 성과 요소를 면밀히 분석하고 파악하는 작업이 필요한 시점이라 할 수 있다. 성과 요소를 구체화하는 것이 향후 한국 해외봉사단(WFK)의 합리적이며 지속가능한 성과평가 중장기 전략 수립에 초석이 될 것이다.

개발에 있어서 해외봉사가 미치는 성과를 체계적으로 분석한 연구는 해외에서 종종 이루어졌지 만 아직 국내에서는 전례가 없었다. 예컨대, 최근 Lough \& Matthew(2013), Australian Red Cross(2014a,b), Burns et al.(2015) 등의 해외연구팀은 현장중심 연구를 통해 해외봉사단의 성 과요소를 종합 분석한 보고서를 출간한 바 있으며, 해외봉사단의 성과측정 및 관리에 관해서는 Franco \& Shahrokh(2012), Haddock \& Devereux(2015), Lough, Thomas, \& Asbill(2015) 등 다수 연구팀이 연구한 바 있다. 국내에서는 주성수 외(2014)의 해외봉사단 효과성 증진 연구, 홍문숙 외(2016)의 WFK의 성과모형 및 지표개발 연구, 이태주 외(2016)의 WFK 종합평가 등이 있다.

상기 선행연구에서 해외봉사의 개발 효과에 대한 조사, 성과관리 사례, WFK 성과관리 지표개 발 방안이 다루어졌음에도 불구하고, 기 연구들과 $\mathrm{WFK}$ 사업 간에는 여전히 괴리가 존재한다. 그 괴리는 즉, 기존 연구들이 $\mathrm{WFK}$ 성과를 위한 구체적 방안의 수립에 적절히 활용되지 못하고 있다 는 점이다. 특히 국내에서도 $\mathrm{WFK}$ 성과체계 수립과 관련된 연구가 종종 진행되었음에도 불구하 고, WFK 성과체계를 현장에 적용하기 위해서는 다소 부족한 실정이다. 이는 국내외 문헌조사를 통해 실증적 증거와 배경지식을 기반으로, WFK 성과관리 전략수립에 있어서 중장기적으로 활용 및 적용 가능한 추가적이고 심층적인 연구 및 제언 도출이 필요함을 시사한다. 때문에 현 시점에 서는 해외봉사가 개발에 주는 성과에 대한 깊고 포괄적인 문헌검토 및 분석이 시의성, 당위성, 필 요성이 높은 연구라 할 수 있다.

본 연구에서는 지금까지 연구에서 지나치게 학술적이고 추상적인 분석을 통해서 현실적용의 한 계점을 가지던 해외봉사단의 성과와 성과분류체계를 재분석해보고자 한다. 아울러 그 분석 결과 를 바탕으로 보다 실질적이고 현실 적용 가능한 $\mathrm{WFK}$ 사업의 성과평가 중장기전략수립을 위한 함의를 도출하고자 한다. 


\section{II. 주요 개념 및 이슈}

본 장에서는 해외봉사의 기본 개념, 해외봉사를 통한 혜택을 받는 집단, 봉사활동에서 기술의 중요성, 봉사활동 기간의 중요성, 봉사활동 방향의 중요성을 포함한 성과 관련 기본 이슈를 정리 하고자 한다.

\section{1. 해외봉사란}

해외봉사란, 지역사회를 위해 서비스를 제공하는(serve) 단체의 업무 혹은 프로젝트의 업무를 수행하기 위해 봉사단원이 타국으로 건너가 봉사활동을 수행하는 것을 말한다(Australian Red Cross, 2014a:6). 한국의 KOICA 및 일본 JICA를 비롯한 몇몇의 공여국, 공여기관 및 민간단체 들은 국가 $\mathrm{ODA}$ 정책 수행에 있어서 해외봉사단 사업을 활용하고 있다. 보편적으로 해외봉사 사 업은 크게 두 가지를 목표로 삼는다. 첫째, 파견지역을 지원(aid)하여 지역의 중점 개발과제에 기 여한다. 둘째, 봉사 단원에게 보람 있는(rewarding) 경험을 제공한다. 봉사활동에 있어서 이러한 두 가지 목표 중 무엇이 우선순위인지는 파견기관 및 봉사단원이 결정한다. 봉사단원의 여행경비 및 생활비는 파견기관이 제공하기도 하지만, 단원 자비로 생활비 및 프로젝트 비용을 부담하기도 한다. 봉사활동 기간은 몇 주에서 길게는 몇 년까지 이어진다(Australian Red Cross, 2014a:6).

\section{2. 해외봉사를 통해서 누가 혜택을 받는가}

해외봉사활동을 결심하도록 만드는 동력은 타인을 돕고자 하는 욕구이다. 그러나 해외봉사 경 험이 수원국 지역사회와 봉사단원 중 과연 누구에게 혜택을 주는지에 대한 논쟁이 있다. 특히, 봉 사단원이 수원국 지역사회 기반 프로젝트나 환경보존 등의 사업에 참여하여 경험을 얻기 위해 직 접 비용을 지불하는 '봉사여행(volunteer tourism)'의 증가로 상기 논쟁이 고조된 바 있다. 해외 봉사는 봉사단원 개인에게 활동경험 등 근본적 혜택을 주는 동시에, 취약계층을 돕는 개발파트너 혹은 기관을 지원하는 개발의 도구라 할 수 있다(Australian Red Cross, 2014a:7). 바로 이러 한 점 때문에 해외봉사가 직간접적으로 개발에 기여를 할 수 있는 여지가 많다. 


\section{3. 봉사활동에 기술(skill)이 중요한가}

봉사단원의 전문성이나 기술은 봉사활동의 결과를 결정하기 때문에 중요하다. 예를 들어, Australian Volunteers for International Development (AVID) 프로그램 산하의 적십자사(Red Cross)는 재난관리 전문가, 직업치유사(occupational therapists), 군수전문가(logisticians), 경 제학자 등을 포함한 많은 전문가들을 봉사단원으로 내세워 파견한다. WFK도 마찬가지로 월드프 렌즈자문단 사업을 통해 퇴직 또는 퇴직예정자 중 특정 분야 (행정, 교육, 의료, 농업, 정보통신, 산업기술 등)의 경험과 지식을 보유한 전문가들을 1 년간 해외에 파견하고 있다. 이 밖에도 월드 프렌즈 과학기술지원단은 수원국의 대학교, 연구소 등에 파견되어 1년간 공동연구와 과학기술 관 련 교육활동을 수행하며, 월드프렌즈 IT봉사단은 우리나라의 IT전문가를 수원국에 파견하여 단기 간(4주) 혹은 한달 이상(2-3개월) IT교육 (예: 중급 오피스 과정 교육) 및 IT프로젝트 (예: 현지 기관 홈페이지 구축) 등을 수행한다. 이렇듯 특정 기술은 특정 봉사활동 임무 수행을 위한 중요한 도구라 할 수 있다.

기술전문가(technical specialist)는 광범위한 원조(aid) 분야에서 널리 활동하고 있지만 해외 봉사단원과는 차이가 있다. 해외봉사단원은 기술전문가와 다르게, 단순하게 기술을 이전하거나 준다는 단방향성의 활동을 하는 것이 아니라, 기술을 상호교환하고 서로에게 영감을 주는 교류에 보다 초점을 둔 활동을 진행한다고 볼 수 있다. 즉, 해외봉사활동은 기술의 교환에 있어서 봉사단 원과 수원기관 측 양방이 참여함으로써 서로 영감을 얻고 일하는 방법을 배우는 것이라 할 수 있 다(Australian Red Cross, 2014a:7).

\section{4. 봉사활동 파견 기간이 중요한가}

해외봉사활동의 기간은 보통 단기 (6개월 미만)와 중기 (12 24개월)로 나눌 수 있는데, 선행 연구에 의하면 봉사활동 기간이 길수록 봉사활동 결과가 더 좋으며, 이는 봉사단원이 새로운 문 화와 수원기관 및 지역사회 프로세스에 적응하고 친숙해지는 시간을 더 많이 갖게 될 때 나오는 긍정적 결과라 할 수 있다(Australian Red Cross, 2014a:7). VSO, UNV, AVI 등 주요 기관의 경우 보통 1 2년 정도가 파견 기간으로 설정되어있고, $\mathrm{AVID}$ 는 6 개월에서 2 년까지로 되어있으 며, 평균적으로 12 개월 정도의 업무가 주를 이룬다.

WFK도 봉사단 파견기간을 프로그램별로 약 2-3주 부터 (월드프렌즈 청년봉사단) 2년 (월드프 렌즈 $\mathrm{KOICA}$ 봉사단)으로 설정하고 있다. $\mathrm{KOICA}$ 의 월드프렌즈사업부에서 매년 실시하는 만족도 
조사 결과를 보면, 파견기간과 봉사단원 및 파견기관 만족도결과 점수 간에 뚜렷한 상관관계는 없는 것으로 사료된다. ${ }^{2)}$

이처럼 파견기간과 성과 간에 뚜렷한 계량적 연관성의 부재에도 불구하고, 몇몇 연구들은 효율 적인 모니터링과 평가 데이터로서 봉사활동의 기간을 강조한다(Australian Red Cross, 2014b:22). 예를 들어, 중동지역에서 수행한 AVI 봉사 프로그램의 경우, 봉사단원의 업무 수행 기간이 길어 질수록 봉사단원과 수원기관 양쪽 모두 목표를 달성할 가능성이 커지며, 수원기관에 대한 이해를 높일 수 있는 기회를 확보하게 된다고 평가한다(Australian Red Cross, 2014b:22).

그러나 장기 봉사활동은 효과적이고, 단기 봉사활동은 비효율적이라는 인식은 '봉사여행 (voluntourism)' 또는 '갭이어 봉사활동(gap year volunteering)' 등의 신개념 봉사활동의 등장 으로부터 비롯되었다(Australian Red Cross, 2014b:23). 수원국 측면에서는 봉사여행이나 갭이 어를 목적으로 한 '방문객'으로부터 받는 혜택은 거의 없고, 오히려 이러한 단기 프로그램에 대한 부정적인 선입견이 강화되는 경향이 있다(Australian Red Cross, 2014b:23). 예를 들어, VSO는 2006년 갭이어 프로그램의 활성화 및 확대가 새로운 형태의 식민주의 위험을 내포하고 있다는 점을 공식적으로 발표한 바 있다. 이는 배움보다는 단기간의 봉사를 강조함으로써 '모든 것은 우리 (선진국)에 대한 것'이라는 태도를 강화할 수 있기 때문이다(Australian Red Cross, 2014b:22). 이는 봉사단원의 연령대가 어리거나 단기로 파견된 경우에 기관 직원과의 관계가 다소 멀거나 냉 담한 경우도 있다는 기존 문헌(Perold et al., 2011; Lough \& Matthew, 2013:15에서 재인용) 을 뒷받침한다. 심지어 단기 봉사활동이 비용 측면에서도 비효율적이고, 업무의 지속성도 저해할 수 있는 요인이 된다고 분석하는 연구도 있다(Sherraden, Lough, McBride, 2008: 405; Australian Red Cross, 2014b:23에서 재인용).

하지만 봉사단원이 지속가능한 참여 부문에 단기간 활동하는 것은 오히려 단기 봉사활동의 연 속성을 강화할 수 있으며, 실제로 6 개월 미만의 봉사활동이 수원국에 놀라운 성과를 가져온 경우 가 종종 있다(Australian Red Cross, 2014b:23). 예를 들어, 단순한 업무시간보다는 업무 기획 에서부터 봉사단원과 수원기관 간의 관계형성을 비롯하여 다양한 요소를 고려하면 연속성을 보장 할 수 있다. 특히, 단기 봉사활동은 수준 높은 전문가를 필요로 하는데, 이들은 장기 봉사자들을 보완하는 역할을 담당한다. UNV의 세계 봉사활동 보고서(2011b) 역시 단기 봉사단원의 업무를 장기 봉사사업의 한 부분으로 포함하는 전략이 효율적이라고 밝혔다. 특히 단기봉사단원의 업무 가 수원기관의 요구에 따라 장기 개발 목표와 합쳐질 경우에는 장기적으로 기여를 할 수 있다 (Australian Red Cross, 2014b:24). 단적인 예로, 국제 NGO단체인 해비타트의 단기 봉사활동 
은 본국에서의 9-12개월간 기금마련과 홍보활동을 펼치고, 이후 현지에서 약 1-2주 봉사 업무를 수행한다. 주요 업무는 안전하고, 적절한 주거지를 구축하는 것이며, 이는 수원국 지역사회 구성 원들의 협력과 지시에 따라 수행된다. 이러한 형태의 활동은 성과평가가 용이하며 단기 활동으로 적합한 특징이 있다. 이렇듯 봉사활동의 효과를 둘러싼 단기와 장기간 봉사활동 간의 이분법에 대한 이슈는 쉽게 단정 짓기 어렵다.

\section{5. 봉사활동의 방향: 해외봉사단원을 누가 파견하며 누가 수원하는가}

통상적으로 선진국·북쪽(Global North) 측의 봉사단원들이 개도국·남쪽(Global South) 측 의 프로젝트나 조직 및 기관에 파견되는 방식으로 해외봉사활동이 이루어졌다. 이는 결과적으로 개발모델과 접근법이 선진국에서 고안된 것으로 비중이 쏠리게 되는 현상을 초래했다. 그러나 점 점 남남(South-South) 협력에 대한 흥미와 연구가 증가하고 있고, 이러한 추세는 봉사파견기관 의 남남 봉사활동의 실천 증가에서도 엿볼 수 있다. 이러한 추세는 지속가능개발이 무엇인지에 대한 기존의 비판적 사고(critical thinking)에 변화가 일고 있음을 반영한다(Australian Red Cross, 2014a:8).

봉사활동의 방향(directionality)에 대해 더 깊이 들어가자면, 포스트 식민주의 관점에서 해외 봉사활동은 북-남 방향에 의해 주도된 불평등한 역사적, 구조적 힘에 의한 사상의 순환이라고 할 수 있다(Australian Red Cross, 2014b:24에서 재인용). 즉, 개도국을 대상으로 하는 해외봉사 파견활동을 과거의 식민주의와 온정주의(paternalism)의 역사로부터 나온 것으로 보는 것이다 (Australian Red Cross, 2014b:24-26). 이는 많은 해외봉사활동 연구 주제가 남쪽에 미치는 북쪽 봉사단원의 영향력을 다루고 있다는 점에서도 확인할 수 있다. 즉, 북-남의 해외봉사활동 역학이 불평등한 역사적 유산에 근거하고 ‘북이 남에게 해주는 것'이라는 개발 개념에 치우쳐있으 며, 북쪽의 정부가 주도하는 글로벌 파트너십의 '소프트 외교'의 하나로서 인식되기도 하는 것이 다. 이러한 인식은 지극히 상업적(commercialized)이고, 널리 접할 수 있는 해외봉사의 기회가 북쪽 사람들에게 치우쳐 제공됨에 따라서 강화된다(Australian Red Cross, 2014b:24). 더불어, 남쪽의 전통적인 봉사활동이나 상호 원조가 '봉사활동으로서 정의되지 않고 무시된다는 점이 지 적되기도 하는데, 예를 들어, 남아프리카의 Ubuntu(공유정신) 개념이나 몽골에서 주거 천막을 공 사하기 위해 현지 지역사회가 함께 협력한 사례는 우리가 별로 주목하지 않는 봉사활동인 점을 들 수 있다(Georgeou, 2012:14; Australian Red Cross, 2014b:24에서 재인용).

개발 분야에서의 신식민주의를 바로잡기 위한 연구들이 종종 있는데, 그 중 Devereux (2008: $361)$ 는 소프트 외교의 한 부분으로써의 해외봉사단원에 대한 시각을 제시한다. 즉, 대다수의 해 
외봉사단파견조직은 사실 비정부기구이며, 해외봉사활동에 국내외 지역사회의 가치, 연계, 거버넌스 구조가 반영됨으로써 개도국 지역사회의 독립성과 자주성이 독려될 수 있다는 주장이다. 또한, 해 외봉사는 권한과 정부기관을 차치한 북과 남 간의 특별한 밀회라는 점도 강조할 수 있다. UNV의 경우, 북과 남의 일반 시민들이 봉사단원으로 활동하고 있으며, 설령 풍부한 해외 경험이나 개인 적인 자금이 부족할 지라도 봉사단원으로 파견되는 경우가 많다. 통계적으로도 UN 봉사단원의 약 70\%가 남쪽에서 모집된다(Australian Red Cross, 2014b:26).

또한, 문화적, 지리적 배경의 근접성 등으로 인해 아시아 국가 간의 남-남 봉사활동이 증가되 고 있는 점을 들 수 있다. 특히, 2010년을 기준으로 아시아 파견기관에서 $73 \%$ 가 동남아시아로, $54 \%$ 가 남아시아로 봉사단원을 보냈으며, 아시아뿐만 아니라 VSO, Progressio, Fredskorpset를 비롯한 서구 파견기관에서 남-북으로뿐만 아니라 남-남 봉사파견이 증가했다는 점이 밝혀진 바 있다(Australian Red Cross, 2014b:26). 지속가능한 개발 관점에서, 남-남 봉사활동과 현지 봉 사문화의 가치를 강조하는 것은 북-남 방향의 낡은 개발 패러다임에서 벗어날 수 있는 가능성을 보여준다.

덧붙여, 최근에는 해외봉사 연구에 남쪽 수원기관의 관점 반영이 증가하고 있는 추세이다. 즉, 과거에는 해외봉사활동 관련 연구는 전통적으로 북쪽으로 돌아온 귀국봉사단원들로부터 정보를 수집하는 방식으로 이루어졌다면, 최근에는 수원국 지역사회가 봉사활동 결과(outcome)를 어떻 게 경험하고 유지하는지를 더 잘 밝혀내기 위해 수원국 측의 자문 또는 조언(consulting)에 연구 의 초점이 이동하고 있다.

\section{III. 해외봉사가 개발에 주는 성과 요소 및 분류}

이번 장에서는 상기 명시한 해외봉사 성과관련 주요 이슈 외에도, 보다 거시적으로 해외봉사와 개 발 간 연계를 분석하고, 해외봉사가 개발에 주는 성과 요소를 세부적으로 분류하여 분석하고자 한다.

\section{1. 해외봉사와 개발 간 연계}

\section{가. 개발과 해외봉사}

봉사활동은 지속가능한 개발에서 필수적인 요소라 할 수 있다. 봉사활동이 지역사회의 주인의식 과 포함성(inclusion)을 촉진하며, 이는 개발활동의 지속가능성을 촉진하기 때문이다(Australian 
Red Cross, 2014a:7). 또한 봉사활동은 시민이 개발에 참여할 수 있는 실천적(practical) 방법 이자 개인적 표출이기도 하다. 2013년 전 세계 50 개 봉사관련 기관이 서명한 지속가능개발을 위 한 파리합의(The Paris Accord on Volunteering for Sustainable Development)에서는 봉사 를 '참여적 민주주의, 사회의 정의, 공정하고 포함적인 성장, 그리고 환경 보호에 필수적' 임을 명 시하고 있다. ${ }^{3)}$ 호주 적십자사는 봉사활동이 지역사회 구축과 지속가능개발의 중심임을 명백히 인 정하고 있다(Australian Red Cross, 2014a:7). 각국 해외봉사단 역시 아래〈표 1〉과 같이 대부 분 파견 목적을 개발협력과 연계지어 설정하고 있다.

제 I 장

제 II 장

섹

터

\begin{tabular}{|c|c|}
\hline 기관 & 목적 \\
\hline 한국 KOICA & $\begin{array}{l}\text { - 개도국 현지주민의 삶의 질 개선 } \\
\text { - 대개도국 우호협력관계 및 양국국민의 상호이해 증진 } \\
\text { - 해외봉사활동 경험의 사회 환원 }\end{array}$ \\
\hline $\begin{array}{c}\text { 미국 } \\
\text { Peace Corps }\end{array}$ & $\begin{array}{l}\text { - 대상국 국민들이 훈련된 인력을 필요로 하는 욕구를 충족할 수 있도록 지원 } \\
\text { - 대상국 국민들의 미국인에 대한 이해증진 } \\
\text { - 미국인들의 타국민들에 대한 이해증진 }\end{array}$ \\
\hline 영국 VSO & - 빈곤퇴치를 위한 공동의 노력 전개 \\
\hline 호주 AVID & $\begin{array}{l}\text { - 수원국 지역의 개발 노력의 지속가능성 강화 지원 } \\
\text { - 교훈과 상호 교류를 통한 국제 협력의 정책과 실행 개선에 기여 } \\
\text { - 장기적인 관계 구축과 호주의 개발 노력에 기여하도록 사람들과 조직을 연계 } \\
\text { - 해외봉사를 통한 호주와 호주인의 글로벌 시민정신 증진 }\end{array}$ \\
\hline 일본 JOCV & $\begin{array}{l}\text { - 개도국의 경제와 사회의 개발/복원에 기여 } \\
\text { - 개도국과 일본의 상호 우호와 이해 증진 } \\
\text { - 일본 사회에 봉사활동 경험의 활용 }\end{array}$ \\
\hline
\end{tabular}

출처: 주성수, 조영호, 이란희, 김이경 (2016), p.37를 저자가 재구성

이처럼 주요 해외봉사단 파견 목적이 개도국의 삶의 질 개선, 빈곤퇴치, 지역개발, 경제와 사 회 개발 등과 같은 개발의제에 필수적인 단어를 명시하고 있는 것으로 보아, 대개도국 개발성과 달성이 봉사단 파견의 주요 목적임을 확인할 수 있다. 이는 세계 주요 봉사단 파견기관이 해외봉 사를 개발협력 수단으로 인식하고 있다는 점을 분명히 보여준다.

\section{나. 지속가능한개발(SDGs)과 해외봉사사업}

해외봉사는 SDGs 달성을 위한 강력한 범분야적 이행수단(powerful cross-cutting means of implementation)으로서, SDGs 달성에 필요한 교육, 보건, 농업, 거버넌스, 경제 등의 분야에

3) France Volontaires https://www.france-volontaires.org/MMG/pdt/the-paris-accord-en.pdf (접속 2016.9.14.) 
긍정적 영향을 미칠 수 있음이 전 세계적으로 인정되고 있다. 전 세계 해외봉사단 파견 연합체인 International Forum for Volunteering in Development (FORUM)4)은 SDGs 체제 하에서 해 외봉사의 기여와 역할 강화를 위하여 다양한 노력을 펼치고 있으며, 구체적인 전략으로는 (1) 개 발협력 수단으로서 해외봉사의 입지 확대, (2) 해외봉사의 영향 측정 및 문서화, (3) 봉사의 가치 에 대한 정보를 광범위하게 공유, (4) 개발을 위한 해외봉사 지지 기반 강화, (5) 봉사단 연합 확 대, (6) 봉사단, 파트너, 이해관계자 등과의 정기적 소통을 통하여 SDGs 달성을 위한 해외봉사의 역할을 설파, (7) 봉사를 평화 및 개발 의제에 통합이 있다.5)

$\mathrm{UNV}$ 역시 봉사활동이 다양한 방식으로 $\mathrm{SDG}$ 목표 1 17에 해당하는 모든 영역에서 1개 이상 의 목표에 기여할 수 있다는 점을 강조한다(아래〈표 2〉 참조) (UNV, 2015:5). 예를 들어, 봉사 단원은 보건(목표 3), 교육(목표 4), 물과 위생(목표 6), 재생가능한 에너지(목표 7), 지속가능한 생태계(목표 $13,14,15)$ 등의 영역에서 기술적 전문성을 제공할 수 있다. 봉사단원은 기술 배양, 역량강화 등에 기여하여, 노동시장 접근성이 낮은 현지 주민들(특히 청년)의 취업가능성 증진에 기여할 수 있다(UNV, 2015:5). 또한 봉사단원은 모범적 태도 제시, 행동의 변화 동기부여 및 촉 발 등에서 그 효과성이 입증된 바 있다. 이러한 활동은 성평등(목표 5), 물과 위생(목표 6), 지속 가능한 소비(목표 12), 기후변화 대응(목표 13), 사회적 자본과 사회 통합 강화를 위한 화해, 관 계, 신뢰회복(목표 16) 등에 적용될 수 있다. SDGs 달성을 위해 봉사단원이 할 수 있는 활동을 정리하면 〈표 2〉와 같다.

\section{〈표 2〉SDGs 달성을 위해 봉사단원이 할 수 있는 활동}

\begin{tabular}{c|l}
\hline 분류 & \multicolumn{1}{c}{ 활동 내용 } \\
\hline 인식제고 & $\begin{array}{l}\text { 소외지역, 소외민을 대상으로 하는 현지 캠페인 활동, 창의적 접근법을 통해 SDGs 내재화에 } \\
\text { 기여 }\end{array}$ \\
\hline 기술적 전문성 제공 & $\begin{array}{l}\text { MDGs 미완수 영역(목표 1 5)에서 해당하는 분야에서 필수적 기초 서비스 보완 및 } \\
\text { 기술역량이 부족한 부분에서 기여(목표 6, 7, 13 15) }\end{array}$ \\
\hline $\begin{array}{c}\text { 모범적 행동 및 } \\
\text { 태도 설정 }\end{array}$ & $\begin{array}{l}\text { 행동 및 태도 변화 촉발을 통해 의제의 효과성 강화와 현지 SDGs 기여에 대한 지식과 의지 } \\
\text { 배양(목표 5, 6, 12, 13, 16) }\end{array}$ \\
\hline 사람의 참여 & $\begin{array}{l}\text { 현지인이 당면한 사안에 대하여 기회의식 및 주인의식 배양을 통해 집단적 행동을 이끌어 } \\
\text { 내고 기획, 이행, 모니터링에 있어 참여도를 제고(목표 17) }\end{array}$ \\
\hline 기술역량의 개발 & \begin{tabular}{l} 
지식 및 경험 전수를 통한 모든 영역에서의 역량 강화와 현지 전문성의 확산 촉진(목표 8 등) \\
\hline 데이터 수집
\end{tabular} \\
$\begin{array}{l}\text { 참여형 모니터링, 대민 활동, MY World 2030 조사와 같은 조사수단의 확산 등을 통해 } \\
\text { SDGs 달성도 평가와 현지 전문성 활용 }\end{array}$ \\
\hline
\end{tabular}

출처: UNV (2015) \& p.5-6을 저자가 재구성

4) FORUM은 1964년 결성된 해외봉사단 파견 기관들의 글로벌 네트워크이며(캐나다 소재), 매년 IVCO(해외봉사단 파견기 관) 연례회의 개최를 담당하는 조직임. 1964년 창립되어, 2000년까지 유럽을 중심으로 운영하다가 2000년 이후 아시아 국가 등도 적극적으로 참여 중임. KOICA는 2013년에 가입하여 2017년 IVCO 회의 주최 예정임.

5) FORUM 홈페이지 http://forum-ids.org/conferences/ivco/ivco-2015/the-tokyo-call-to-action/ (접속일 2016.4.29.) 
한국의 경우, $\mathrm{WFK}$ 봉사단은 $\mathrm{SDGs}$ 목표에서 강조하는 교육, 보건, 지역개발 등 다양한 분야 의 활동을 수행하기 위해 파견이 되고 있으며, 단원은 자신의 분야 전문성을 활용하여 현지개발 에 기여할 수 있다. 각 활동은 아래〈표 3〉과 같이 SDGs 목표 분야와 직간접적으로 연계된다.

〈표 3〉 월드프렌즈코리아(WFK) 분야별 활동 내용과 SDGs 목표 간 연계

\begin{tabular}{|c|c|c|}
\hline 분야 & 세부 활동 내용 & SDGs 목표 \\
\hline 교육 & $\begin{array}{l}\text { - 학교 교사 교육 실시 } \\
\text { - 방과 후 수업 운영(보충 수업) } \\
\text { - 신규 교육 커리큘럼 개발(언어, 컴퓨터 등) } \\
\text { - 학교 인프라 개선 사업 추진 } \\
\text { - 학생 교육권 강화 캠페인 } \\
\text { - 소수민족, 여성, 장애인 등 소외계층 교육 강화 }\end{array}$ & $\begin{array}{l}\text { 목표 } 1 \text { (빈곤퇴치) } \\
\text { 목표 } 4 \text { (교육) } \\
\text { 목표 } 5 \text { (성평등) } \\
\text { 목표 } 8 \text { (고용) } \\
\text { 목표 } 10 \text { (불평등해소) }\end{array}$ \\
\hline 보건 & $\begin{array}{l}\text { - WASH 프로그램 기획 및 운영(학교, 복지시설 등) } \\
\text { - 낙후 및 소외지역 보건 활동 실시 } \\
\text { - 의료시설(병원, 보건소) 진료 환경 개선 사업 추진 } \\
\text { - 의료진 역량강화 활동 추진(신규 기자재 활용 교육 실시) } \\
\text { - 보건 당국 업무 지원 }\end{array}$ & $\begin{array}{l}\text { 목표 } 1 \text { (빈곤퇴치) } \\
\text { 목표 } 3 \text { (보건) } \\
\text { 목표 } 5 \text { (성평등) } \\
\text { 목표 } 6 \text { (물/위생) }\end{array}$ \\
\hline 농촌개발 & $\begin{array}{l}\text { - 현지 농어촌 의식 개선 } \\
\text { - 농어촌 지도자 교육 실시 } \\
\text { - 현지 마을 인프라 개선 사업 추진 } \\
\text { - 현지 농산물 판로 개척 활동 실시 } \\
\text { - 농어촌 경제활동 촉진 지원 } \\
\text { - 농업생산성 증대 활동 실시 }\end{array}$ & $\begin{array}{l}\text { 목표 } 1 \text { (빈곤퇴치) } \\
\text { 목표 } 2 \text { (기아퇴치) } \\
\text { 목표 } 5 \text { (성평등) } \\
\text { 목표 } 8 \text { (고용) } \\
\text { 목표 } 10 \text { (불평등해소) } \\
\text { 목표 } 12 \text { (소비생산) }\end{array}$ \\
\hline 공공행정 & $\begin{array}{l}\text { - 공공서비스 전달 개선 지원 } \\
\text { - 공공기관 내(학교, 병원, 시청 등) 전자시스템 활용도 제고 역량강화 } \\
\text { 활동 실시 } \\
\text { - I 설비 활용 매뉴얼 작성 및 보급 }\end{array}$ & $\begin{array}{l}\text { 목표 } 10 \text { (불평등) } \\
\text { 목표 } 12 \text { (안전) } \\
\text { 목표 } 16 \text { (거버넌스/평화) }\end{array}$ \\
\hline 과학기술 & $\begin{array}{l}\text { - 적정기술 활용 및 보급 활동 실시 } \\
\text { - 현지 기술 활용력 제고 }\end{array}$ & $\begin{array}{l}\text { 목표 } 8 \text { (고용) } \\
\text { 목표 } 12 \text { (소비생산) }\end{array}$ \\
\hline
\end{tabular}

출처: KOICA (2016) 월드프렌즈교육원 내부자료

궁극적으로 봉사활동은 다양한 방법으로 직간접적으로 SDGs 각 목표 달성을 지원할 수 있다.

\section{2. 해외봉사의 성과 및 성과 분류체계 분석}

\section{가. 배경 및 최신 동향}

해외봉사가 개발에 계량적으로 미치는 효과에 대한 연구는 아직까지 많이 없다고 할 수 있다. 또한 봉사활동이 봉사단원에게 주는 혜택을 조사한 연구는 종종 있었지만, 봉사단원들이 빈곤과 지역사회에 미치는 영향에 대해 조사를 한 연구는 제한적이다. 최근 봉사의 기여를 개발과 연계 
하여 탐구한 연구는 대표적으로 VSO \& IDS에서 출간한 봉사의 가치(valuing volunteering) 시 리즈(Burns et al., 2015)와 국제봉사협력기구(IVCO)에서 조사한 회색문헌연구 보고서(Lough, Thomas, \& Asbill, 2015:3-16)가 있다.

특히 Lough 외 연구진(2015)은 FORUM 회원 봉사단체 8곳으로부터 124개의 비공개 평가보 고서를 수집하여 조사를 한 결과, 지난 15 년간 다수의 개발 프로젝트에서 해외봉사단원이 활동한 이유가 MDGs 달성에 일조하기 위함이었음에도 불구하고, MDGs 달성을 위한 진전을 측정하는 표준적 지표를 사용하는 평가보고서가 한 개도 없다는 문제를 발견했다. 또한 다수의 보고서에서 봉사활동이 개발에 미치는 영향에 대해서 분석하기보다는 일화적(anecdotal) 증거를 내세워 성과 를 평가하고 있다는 점을 규탄했다(Lough et al., 2015:3-4). 이것은 아마도 봉사단원이 개발 사업에 기여하는 다양한 주체들 중 하나로써 '복잡하게 얽힌 현실(messy reality)'에 속해있기 때 문일 것이라고 저자는 해석한다(Lough et al., 2015:4). 아래〈표 4〉는 해외봉사단의 성과 요소 및 분류에 관련한 최신 주요문헌 4 개를 정리·요약한 것이다.

〈표 4〉 해외봉사단 성과요소 및 분류에 관한 주요 최신연구(국외) 요약

\begin{tabular}{|c|c|c|}
\hline 연구 수행자 & 연구 방법 및 내용 (요약) & 성과 분류 및 요소 \\
\hline $\begin{array}{l}\text { Lough \& } \\
\text { Matthew } \\
(2013)\end{array}$ & $\begin{array}{l}\text { 수원국(페루, 케냐) 현장중심 선행연구를 } \\
\text { 검토한 결과, 해외봉사활동의 가치 및 } \\
\text { 기여 요소를 봉사 특유 가치 (added } \\
\text { value), 중기적 효과, 장기적 효과로 분 } \\
\text { 류하여 제시 }\end{array}$ & $\begin{array}{l}\text { 1. 봉사 특유 가치(신뢰, 새로운 아이디어, 명성, 투명성, } \\
\text { 영감, 낙천관) } \\
\text { 2. 중기적 outcome(사회적자본, 외부자원, 우정, 인권의식, } \\
\text { 기술이전, 혁신, 시민참여, 지역책임감, 역량개발) } \\
\text { 3. 장기적 impact (웰빙, MDGs, 문화간 이해) }\end{array}$ \\
\hline $\begin{array}{l}\text { Australian } \\
\text { Red Cross } \\
(2014 a, b)\end{array}$ & $\begin{array}{l}\text { 지역사회 및 수원기관을 중심으로 개발 } \\
\text { 의 도구(tool)로써의 해외봉사활동의 효 } \\
\text { 과 및 혜택 요소를 분석하여 제시 }\end{array}$ & $\begin{array}{l}\text { 1. 수원국 지역사회 봉사에 영감 부여 및 지역 봉사 강화 } \\
\text { 2. 장기적 기술교환/이전 기반 마련 } \\
\text { 3. 봉사단원들/수원국 기관들이 함께 업무하는 시간은 업 } \\
\text { 무의 적절성 및 지속가능성 증가 } \\
\text { 4. 개발에 관한 기존 모델/전통에 도전 }\end{array}$ \\
\hline $\begin{array}{c}\text { Burns et al. } \\
\text { (2015) }\end{array}$ & $\begin{array}{l}\text { 수원국 현지 } 3,700 \text { 여명의 봉사활동 관 } \\
\text { 계자들을 대상으로 질적, 참여적 연구를 } \\
\text { 통해 지속가능개발을 위한 봉사 특유 기 } \\
\text { 여 요소를 분석하여 제시 }\end{array}$ & $\begin{array}{l}\text { 1. 극빈층/소외층으로 공공서비스 전달 } \\
\text { 2. 적극적 시민성과 사회적 자본 동원 } \\
\text { 3. 관계 구축(리더십, 의사소통, 인적관리 등 소프트 성과) }\end{array}$ \\
\hline $\begin{array}{l}\text { Lough, } \\
\text { Thomas, } \\
\text { \& Asbill } \\
(2015)\end{array}$ & $\begin{array}{l}\text { 봉사기관 } 8 \text { 곳으로부터 } 124 \text { 개의 비공개 } \\
\text { 평가보고서를 수집하여(회색문헌), 해외 } \\
\text { 봉사 성과를 방해하거나 중재하는 } 5 \text { 가 } \\
\text { 지 요소를 분석하여 제시 }\end{array}$ & $\begin{array}{l}\text { 성과를 중재하는 요소: } \\
\text { - 봉사기반 프로젝트 재정(funding) 부족 } \\
\text { - 파트너 기관들의 역량 부족 } \\
\text { - 봉사활동 준비 부족 } \\
\text { - 지역사회의 참여 } \\
\text { - 프로그램상의 문제 }\end{array}$ \\
\hline
\end{tabular}

출처: 저자 구성 
위 선행 연구 중 Lough \& Matthew(2013)의 연구는 질적, 양적조사를 모두 수행하였으며, 현장중심 선행연구를 검토하여 해외봉사활동의 가치 및 기여의 세부 요소를 그 특성별로 분류한 연구로써, 포괄적이며 향후 성과요소 분류체계 수립에 있어서 활용도가 높은 우수 연구라 할 수 있다. 동 연구에 의하면, 수원국 관점에서 해외봉사의 가치에 대한 선행연구 결과는 다음과 같이 요약할 수 있다.

먼저, 개발효과성(development effectiveness)을 측정하는데 있어서 MDGs 지표나 프로젝트 성과(project performance)같이 가시적이며 공공연한(overt) 요소의 측정에만 치우쳐있는 반면, 해외봉사가 개발에 주는 이론이나 실질적(practical) 가치에 대한 연구는 부족한 상황이다. 따라서 봉사단원이 개발에 가져다주는 감지하기 힘들고 좀 덜 명시적인 기여에 대해 조사를 할 필요가 있다. 예를 들어, 제도구축과 역량개발과 같은 요소는 개발에 있어서 주류적 결과물(mainstream outcomes)로 알려져 있는 반면, 혁신, 책임성, 사회적 포함, 관계의 결속(relational solidarity) 등과 같이 측정하기 애매한 결과물은 비주류적인 결과물로 여겨진다(Lough \& Matthew, 2013:10).

선행연구를 분석해보면, 해외봉사활동의 기여점에 대해 수혜국측이 가장 빈번히 보고한 요소는 역량구축과 기술이전이었다. 특히 기술교환(skills-sharing)은 수원국-공여국 상호간 혜택을 주 었는데, 실제로 대부분 봉사단원은 봉사활동으로 인해 배움을 주는 것보다 본인이 얻는 배움이 더 크다고 보고했다(Lough \& Matthew, 2013:10). 어떤 봉사단원은 본인의 전문성을 이용하여 현지에 지식을 채워주었지만, 대부분의 기술이전은 기초적 기술(basic skills)을 가르치고 기존의 일반적 교육을 증진하는 형식으로 이루어졌다(Lough \& Matthew, 2013:10).

수혜국측이 해외봉사활동의 기여점에 대해 두 번째로 빈번히 보고한 결과물은 개발프로젝트에 봉사단원들이 가져다주는 창의성과 새로운 아이디어였다. 이러한 결과물은 보통 개발프로젝트의 프로세스나 산출물 향상을 위한 특정 혁신이나 제안의 형태로 나타났다. 역량구축에 관련한 아이 디어는 문화적으로나 상황적으로 항상 적절하지는 않았지만, 개발 사업에서 봉착하는 어려움 극 복에 있어서 봉사단원이 신선하고 낙천적인 관점을 제공해주었다. 아이디어 교환과 새로운 학습 은 봉사단원과 지역사회간 상호적으로 일어난다고 보고되었다. 창의성 발휘와 같은 새로운 학습 은 보건이나 교육 분야 등과 관련된 기술적 방면의 결과에 비교해서 실체가 없다고 보일 수 있지 만, 대신 어려운 개발과제를 다루느라 고생하는 직원들에게 가치있는 기여를 한다고 보고되었다 (Lough \& Matthew, 2013:10).

세 번째로 빈번히 보고되는 요소는 바로 자원을 레버리지할 수 있는 관계(instrumental relationships)였다. 이러한 작업성 관계는 보통 사회적 자본(social capital)을 '결합(bonding)' 및 '가교(bridging)' 해주는 레버리지 역할을 해준다고 지각되었다(Lough \& Matthew, 2013:10). 
네 번째로 빈번히 거론되는 봉사단원의 기여는 금전 같은 유형적인 자원을 지역사회와 수원기 관으로 가져오는 것이라 보고되었다(Lough \& Matthew, 2013:10). 또 수원기관은 봉사단원이 수원기관의 인지도를 향상하고, 지역사회 주민 및 자금제공자(funders)의 지역 수원기관을 향한 신뢰와 위신을 높인다고 지각했다. 이 외에도, 우정, 영감, 낙천성, 문화간 이해, 신뢰, 지역사회 의 책임성 등을 포함한 사람과의 관계에 대한 결과 역시 빈번히 보고된 바 있다((Lough \& Matthew, 2013:10-11).

마지막으로, 해외봉사단원은 지역의 시민과 지역봉사단원의 참여에 영감을 줌으로써 시민사회 의 성장에 기여한다는 점이 또 한 가지 결과물로 보고되었는데, 이 결과물은 Post-2015에서 '정 치적 프로세스와 모든 수준에서 시민의 관여에 있어서 대중 참여 증가'가 강조된 가운데, 중요한 요소라 할 수 있다. 지역 조직이 펼치는 노력과 활동에 해외봉사단원이 참여할 때 지역공동체 내 에서의 흥미에도 활기가 더해진다. 여기에 봉사단원의 파견기간이 길수록 지역 주민들과의 라포 (rapport)가 강하게 구축되고, 지역문화의 규범에 대해 친숙한 지식을 쌓는 경향도 있다(Lough \& Matthew, 2013:11).

아래〈표 5〉는 상기 명시한 결과물(outcome)이 선행연구에서 얼마나 자주 해외봉사단원들의 기여도로 거론되었는지를 요약하여 보여준다.

〈표 5〉선행 현지조사연구에 의해 분석된 해외봉사단원들의 기여

\begin{tabular}{c|c|c}
\hline 결과물 (봉사단원들의 기여) 분류 & 거론된 횟수 $\left(\mathrm{n}=19^{*}\right)$ & 총 \% \\
\hline 역량구축 및 기술이전 & 17 & $89 \%$ \\
\hline 혁신과 독창성(ingenuity) & 14 & $74 \%$ \\
\hline 사회적 자본 & 11 & $58 \%$ \\
\hline 자원(resources) & 9 & $47 \%$ \\
\hline 신뢰 & 9 & $47 \%$ \\
\hline UN MDGs & 9 & $47 \%$ \\
\hline 시민 참여 & 8 & $42 \%$ \\
\hline 명성과 존중 & 8 & $42 \%$ \\
\hline 문화간 이해와 다양성 & 7 & $37 \%$ \\
\hline 영감과 낙천감 & 6 & $32 \%$ \\
\hline 우정 & 6 & $32 \%$ \\
\hline 투명성과 책임성 & 3 & $16 \%$ \\
\hline 인권에 대한 의식 & 3 & $16 \%$ \\
\hline
\end{tabular}

출처: Lough \& Matthew (2013) p.11 표를 재구성

* 기여의 횟수에 대한 보고는 각 선행연구가 어떤 요소에 초점을 맞추었는지를 반영하므로 절대적 측정(absolute measure) 으로 해석되어서는 안된다. 
Lough \& Matthew는 이어서 기여를 다음과 같은 요소로 그룹화하였다. 각 요소에 대한 자세 한 분석은 다음 섹션에서 다루도록 하겠다.

제 I 장

〈표 6〉 해외봉사활동의 기여 요소와 분류

\begin{tabular}{|c|c|c|}
\hline $\begin{array}{l}\text { 추가적/봉사 특유의 가치 } \\
\text { (Added Value) }\end{array}$ & $\begin{array}{c}\text { 중기적 결과물 } \\
\text { (Intermediary Outcomes) }\end{array}$ & $\begin{array}{c}\text { 주요 결과물 (Outcomes) 및 } \\
\text { 영향력 (Impact) }\end{array}$ \\
\hline $\begin{array}{l}\text { - 신뢰 } \\
\text { - 새로운 아이디어 } \\
\text { - 명성 } \\
\text { - 투명성 } \\
\text { - 영감 } \\
\text { - 낙천관 및 흥분 }\end{array}$ & $\begin{array}{l}\text { - 사회적 자본 } \\
\text { - 외부 자원 } \\
\text { - 우정 } \\
\text { - 인권에 대한 의식 } \\
\text { - 기술의 이전 } \\
\text { - 혁신 } \\
\text { - 시민의 참여 } \\
\text { - 지역의 책임감 } \\
\text { - 역량 개발 }\end{array}$ & $\begin{array}{l}\text { - 웰빙안녕 } \\
\text { - 새천년개발목표 (MDGs) } \\
\text { - 문화간 이해 }\end{array}$ \\
\hline
\end{tabular}

출처: Lough \& Matthew (2013) p.23 표를 재구성

앞서 본 Lough \& Matthew(2013)의 연구는 구조화 인터뷰(semi-structured interview guide) 방식 등 혼합적 방법론(mixed method approach)을 사용하여 해외봉사의 기여를 분석하 고, 해외봉사의 영향력과 도전과제의 추가 영역을 탐구했다는 점에서 선행연구로서 강점이 있고 주목할 만하다. 그러나 연구 대상국가인 페루와 케냐를 중심으로 조사가 실시되었기 때문에, 본 연구결과를 다른 지역으로 일반화하는 것은 지양해야 할 것이다.

상기 명시한 Lough \& Matthew(2013)의 연구보다는 보다 질적이며 참여적(qualitative and participatory) 연구로, Burns 등(2015)은 2년간 케냐, 모잠비크, 네팔, 필리핀에서 3,700여명 의 봉사 관계자들을 모집하여 조사를 실시했다. 특히 연구의 질문인 '봉사활동이 빈곤에 어떻게 그리고 왜 영향을 주는가?'에 대답하는데 있어서 '참여적 체계 질문(participatory systemic inquiries)'과 ‘체계적 행동연구(systemic action research)' 방법론을 적용했다. 상기 방법을 통 해 체계적 그림과 지도 생성 및 프로세싱, 업무패턴 모니터링, 설문, 이야기 수집과 분석, 관찰, 참여적 사진촬영 및 참여적 영상촬영, 공개적 토론 및 담화와 같은 다양하고 풍부한 자료를 근거 로 결론을 도출했다는 점에서 Burns 외(2015)의 연구가 의미가 있다고 할 수 있다. 동 연구는 지속가능개발을 위한 봉사 특유의 기여를 3가지 요소로 정리했다: (1) 소외층으로 공공서비스 전 달, (2) 적극적 시민성과 사회적 자본 동원, (3) 관계 구축 등 3 가지 요소에 대한 자세한 내용은 추후 섹션에서 다루겠다. 


\section{나. 해외봉사사업 성과 및 봉사단원의 성공에 영향을 미치는 요소}

자세한 성과 요소 및 분류 체계를 알아보기 전, 앞서 요약한 해외봉사의 성과에 영향을 미치는 요소를 언급하도록 하겠다. Lough, Thomas, \& Asbill(2015)은 해외봉사활동의 성과를 방해하 거나 중재하는 5 가지 요소 (재정부족, 역량부족, 준비부족, 참여부족, 프로그램 문제)를 다음 〈표 7)과 같이 요약한다.

〈표 7〉 해외봉사의 성과를 중재하는 5 가지 요소

\begin{tabular}{|c|c|}
\hline 요소 & 내용 \\
\hline $\begin{array}{l}\text { 1. 봉사기반 } \\
\text { 프로젝트 재정 } \\
\text { (funding) 부족 }\end{array}$ & $\begin{array}{l}\text { 다수의 봉사단원은 수원기관이 재정부족을 성과를 방해하는 요소로 꼽았으며, 특히 봉사단원 } \\
\text { 이 수원기관을 떠난 이후의 프로그램 운영 및 지속가능성에 대해 많은 수원기관이 우려한다. } \\
\text { 이를 해결하기 위해, 재정지원은 공여국에만 의존하는 대신에, 카운터파트 자금(counterpart } \\
\text { funding) 구축 및 파트너 기관들의 주인의식을 고양함으로써 해외봉사활동으로 인한 긍정적 } \\
\text { 결과의 효과성과 지속가능성을 보장할 수 있다. }\end{array}$ \\
\hline $\begin{array}{l}\text { 2. 파트너 기관의 } \\
\text { 역량 부족 }\end{array}$ & $\begin{array}{l}\text { 재정, 인적, 조직적 역량 부족, 준비의 부족은 파트너 기관들이 개발프로젝트의 효과를 유지하 } \\
\text { 지 못하는 원인으로 꼽고 있다. 이러한 문제를 해결하기 위해서 파트너기관이 프로젝트를 장 } \\
\text { 기적으로 이행하고 유지할 수 있는 역량을 키우기 위해 사전에 철저한 니즈평가(needs } \\
\text { assessment)를 하는 방안이 있다. }\end{array}$ \\
\hline $\begin{array}{l}\text { 3. 봉사활동 } \\
\text { 준비 부족 }\end{array}$ & $\begin{array}{l}\text { 봉사단원의 활동에 있어서 훈련과 지원 등을 포함한 준비 부족이 공통적으로 지적되는 요소이 } \\
\text { 다. 이러한 문제점을 해결하기 위해 봉사단원이 파견되어있는 동안 활동에 필요한 적절한 코 } \\
\text { 칭, 멘토링, 감독(supervision) 등의 활동 제공이 가능하다면 봉사단원이 보다 효과적으로 활동 } \\
\text { 할 수 있을 것이다. }\end{array}$ \\
\hline $\begin{array}{l}\text { 4. 지역사회의 } \\
\text { 참여 부족 }\end{array}$ & $\begin{array}{l}\text { 지역의 전문가나 지역 주민의 전문성을 잘 활용한 프로그램일수록 현지 주민들은 정책변화에 } \\
\text { 더 적극적이게 되며, 이는 더 지속가능한 변화를 가져다준다. 따라서 프로젝트를 설계, 개발, } \\
\text { 이행하는 등의 과정을 통해서 지역사회의 참여를 이끌어 내고 수혜자에게 권한과 동기를 부여 } \\
\text { 하기 위해 노력해야 한다. 이러한 지역 사회의 참여를 이끌어 내기 위해서는 지역사회의 교육 } \\
\text { 이나 이니셔티브를 통해 성취할 수 있다. 즉, 이니셔티브와 정책 변화가 지속가능한 변화의 주 } \\
\text { 요 요소임을 시사한다고 볼 수 있다. }\end{array}$ \\
\hline $\begin{array}{c}\text { 5. 프로그램상의 } \\
\text { 문제 }\end{array}$ & $\begin{array}{l}\text { 종종 프로그램에 구조적인 문제가 있거나 달성 목표가 너무 방대한 경우 목표를 달성하는 것 } \\
\text { 조차 어려우며, 이로 인해 프로그램 성과에 대해 평가하는 것이 불가능하다. 예를 들어, 파트 } \\
\text { 너기관 측면에서는, 자본 정책이나 직원에 대한 기본 요건을 갖추지 못하는 경우 프로그램 수 } \\
\text { 준에서 구조적 어려움이 생긴다. 프로그램의 M\&E 혹은 프로그램의 디자인과 운영을 개선하는 } \\
\text { 것을 통해서 문제를 해결해 볼 수 있을 것이다. }\end{array}$ \\
\hline
\end{tabular}

출처: Lough, Thomas, \& Asbill (2015) p.16-18를 정리하여 재구성

이 외에도 호주 외교통상부는 인터뷰 등을 통해 AVID 프로그램을 평가한 결과, 성공적인 봉사 단원의 특징과 봉사단원의 성공 및 실패 (중도귀국 등)를 좌우하는 요소를 설명한 바 있다 (아래 〈표 9〉 참조). 
〈표 8〉 성공적인 봉사단원의 특징 (수혜기관 중심)

수원기관의 입장에서 바라본 성공적인 봉사단(successful volunteers)은 몇 가지 공통적인 특징을 가지고 있다. 먼저, 봉사단원이 되기 위해서는 특별한 전문성을 갖추어야 한다는 것에 수원기관 및 파트너 들은 합의하고 있다. 또한 유 창한 영어실력을 강조하고 있으며, 그 외에도 유연함, 적응력, 인내, 적극성, 개방성, 열정이라는 용어들로 성공적인 봉사단원을 정의하고 있다. 아래의 인터뷰는 수원기관에서 바라보는 성공적인 봉사단원이 되기 위해서는 전문성을 바 탕으로 개방적인 사고와 열정을 가지고 활동하는 것이 보다 필요하다는 것을 잘 보여주고 있다.

"봉사단원들은 일반적인 자문가(consultant)들과는 다릅니다. 왜냐하면 그들은 자문만을 제공하며 돈을 벌고자 온 것이 아니고 이 지역에 대해 좀 더 배우고자 하는 자세를 가지고 있기 때문입니다. 우리는 편협한 전문가보다는 열린 마음으로 전략적 사고를 할 수 있는 사람들이 더욱 필요합니다.”

[솔로몬 군도의 수원기관]

봉사단원은 대부분 전문적 기술을 가지고 새로운 아이디어, 접근법, 사기를 불러일으키는 존재로 여겨지며, 봉사단원 의 개인적 자질과 성격은 업무 성공 여부에 분명 중요한 요인이다. 때로는 전문성 정도에 있어서도 해외봉사단원이 전문 유급 자문가(paid technical advisers)보다도 더 낫다고 보고되기도 한다. 비용측면에서도 봉사단원 자문은 일반 자문가보다 더욱 매력적이다.

출처: Australian Government Department of Foreign Affairs and Trade (2014) p.36-37를 정리하여 재구성

〈표 9〉 봉사단원의 성공 및 실패를 좌우하는 요소 (수혜기관 특징)

\begin{tabular}{|c|c|}
\hline 강점 (수원기관 내부) & 약점 (수원기관 내부) \\
\hline $\begin{array}{l}\text { - 적극적인 자기 개발 노력과 봉사단원 } \\
\text { 과의 활발한 교류를 통해 전문성과 } \\
\text { 헌신을 갖춘 직원들로 이루어진 소규 } \\
\text { 모의 안정적인 팀 } \\
\text { - 봉사단원에 대한 지원을 제공함 } \\
\text { - 봉사단원의 업무를 위한 회의 시간 } \\
\text { 을 마련 } \\
\text { - 봉사단원과 다양한 활동을 함께함 } \\
\text { (직원 점심식사 및 현장방문). } \\
\text { - 과거 봉사단원을 초청해본 경험 }\end{array}$ & $\begin{array}{l}\text { - 모든 안건이 } 1 \text { 2명의 선임에 의해 이루어짐으로써 의사결정이 뒤쳐지는 } \\
\text { 기관 } \\
\text { - 기관의 운영체제에 대한 구성원(직원, 봉사단)간의 의사소통 부족 } \\
\text { - 전략적 사고 및 기획의 역량 부족으로 업무수행이 막판까지 이루어지는 } \\
\text { 기관이나 전반적으로 효율성이 떨어지는 기관 } \\
\text { - 평가단이 방문한 모든 기관은 전기와 수도 상태가 비교적 괜찮았지만, } \\
\text { 여전히 기본적 자원 (예: 원활한 인터넷망, 정기적인 전기사용)이 부족한 } \\
\text { 기관 } \\
\text { - 직원들의 낮은 임금은 본업 이외의 추가 업무 및 퇴직으로 이어져 기관 } \\
\text { 내 전반적 사기를 저하 } \\
\text { - 봉사단원을 장기적인 발전과 지속성 강화를 위한 조력자로 이해하기 보 } \\
\text { 다는 단순한 지원으로 인식 }\end{array}$ \\
\hline 기회 (수원기관 외부) & 위협요소 (수원기관 외부) \\
\hline $\begin{array}{l}\text { - 수원기관 및 봉사단원을 지원하기 위 } \\
\text { 한 전문적 네트워크 및 다양한 수단 } \\
\text { 으로의 접근성 확대 }\end{array}$ & $\begin{array}{l}\text { - 기금 마련의 어려움 } \\
\text { - 국제 비정부기구의 운영에 영향을 끼치는 정책 또는 법안의 변화 }\end{array}$ \\
\hline
\end{tabular}

출처: Australian Government Department of Foreign Affairs and Trade (2014) p.53를 정리하여 재구성

위에서 살펴본 요소들은 해외봉사의 성공에 있어서 몇 가지 시사점을 제시한다. 첫째, 수혜기 관 내부의 간단한 개선 만으로 (예: 의사결정 참여자 증가, 의사소통 기회 증가, 전기 및 인터넷 등의 기본시설 확충, 임금 향상, 봉사단원에 대한 이해도 개선 등) 봉사단원들의 활동으로 인한 혜택을 보다 많이 받을 수 있다. 둘째, 봉사단원은 영어실력 향상, 전문기술 향상 등 자기개발을 
통해 봉사활동 성과를 향상시킬 수 있다. 셋째, 봉사활동 성과 극대화를 위해서 선발 과정에서부 터 성공적 봉사단원들의 특징을 가진 지원자들을 선발하면 봉사단의 중도 귀국율을 비롯한 실패 율을 감소시킬 수 있을 것이다. 예를 들어, WFK 봉사단 모집의 지원서 작성 과정에서 유연함, 적응력, 인내, 적극성, 개방성, 열정과 같은 지표에 높은 점수를 받는 봉사단 지원자를 선발하는 것이 향후 봉사단 성과 개선에 효율적일 것이다. 이처럼 수원기관과 봉사단원이 스스로 각 측의 부족함을 파악하여 조치할 수 있다면 양측 모두 봉사활동으로부터의 성과를 극대화할 수 있을 것 이다.

\section{다. 성과의 분류}

본 장에서는 앞 장에서 명시한 최신 선행연구를 통해 조사된 해외봉사 성과요소를 세부적으로 분석함으로써, 요소별로 자세한 내용과 기여 프로세스를 살펴보고자 한다.

본고에서 다루는 해외봉사의 성과 요소와 분류 체계가 종합적이거나 모든 성과의 종류를 아우 르는 것은 아닐 것이다. 그러나 선행연구에 의해 도출된 성과요소와 분류체계를 종합하여 WFK 의 기존 사업목표와 성과모형 틀에 맞추어 재분류를 해 보았다. 즉, 요소의 분류는 홍문숙 외 (2016)6)가 참고한 WFK 성과모형과 일관성을 유지하기 위하여 3가지 측면 (봉사단원, 수원국· 수원기관, 파견국·파견기관)으로 구분하였고, 이를 다시 Lough \& Matthew(2013:23)이 앞서 제시한 단기, 중기, 장기성과로 분류하여 정리하였다.

따라서 아래 섹션에서는 성과의 분류를 (1) 봉사단원 측면의 중기적 성과, (2) 수원국 측면의 단 기성과, (3) 수원국 측면의 중기적 성과, (4) 수원국 측면의 장기적 성과, (5) 파견국 측면의 중기적 성과로 나누어 설명코자 한다.

\section{1) 봉사단원 측면의 중기적 성과}

가) 적극적인 시민성과 사회적 자본 동원

봉사활동을 통해 봉사단원이 얻을 수 있는 중기적 성과로, 봉사단원은 적극적인 시민성과 사회 적 자본을 동원하고 발휘할 수 있다. 봉사활동은 단원에게 새로운 역할과 책임을 시험할 수 있는 기회를 제공해주며, 봉사단원이 사회적 행동을 실행 및 연습하고 참여를 통해 얻은 결과물을 직접

6) WFK 사업의 성과모형, 성과체계 및 지표(안)의 현황과 논의는 추후 연구에서 보다 자세하게 다루어질 것이고, 현황에 대 해서는 홍문숙 외(2016)의 연구보고서를 참고하면 된다. 
체험할 수 있도록 안전한 환경을 제공해준다(Burns et al., 2015:23). 수원국 지역주민 측면에서 도, 단원이 조직한 활동을 목격하거나 이에 참여를 하는 것만으로도 지역주민이 문제에 대해 적 극적 관심을 갖고 이에 대응하도록 동기를 부여할 수 있다. Burns et al.(2015:23)에 의하면, 이 러한 적극성과 사회적 자본을 동원하기 위해서는, 지역사회 스스로 행동을 취하고 지역에 영향을 주는 개발프로그램에 주민이 사실상 기여를 할 수 있도록 지역의 권한강화(empower)가 먼저 필 요하며, 봉사활동에 참여를 지속하기 위해서는, 단원의 활동에 의한 가시적인 성과가 보여야 한다 는 점을 지적한다. 가시적인 성과를 접한 단원이나 지역주민은 봉사에 대해 적극성을 느끼지만, 그렇지 못한 경우에는 빠른 속도로 환멸을 느끼게 되는 경우가 많기 때문이다.

제 I 장

제 II 장

터

제 III 장

\section{2) 수원국 중심의 봉사단 특유 단기성과}

Lough \& Matthew(2013:22)는 해외봉사 특유의 성과를 해외봉사사업 성과모형 실현 과정에 서 중기성과 달성 이전에 일어나는 '매개변수(mediating variables)'라고 명하고 있으며, 이는 곧 단기성과라는 의미로도 해석하고 있다. 이러한 해외봉사 단기성과, 즉, 매개변수(해외봉사의 added value)에는 신뢰, 새로운 아이디어, 명성, 투명성, 영감, 낙천관이 포함된다.

가) 봉사단원-수원국 지역사회 및 수원조직 간의 신뢰 형성

해외봉사단원과 수원국 측 지역사회 및 조직 구성원들 간의 신뢰는 봉사활동의 특유 효과라 할 수 있다. 해외봉사단원에 대한 신뢰 구축은 기존 개발사업 이행 단계뿐만 아니라, 지역사회의 참 여를 도모하는데 중요하다(Lough \& Matthew, 2013:19).

수원국 관계자는 자신의 지역 공동체에 거주하고 현지어를 구사하는 봉사단원이 지역사회의 니즈 와 관심사를 잘 대표해준다고 보았다. 특히 수원국은 봉사단원의 높은 신뢰도를 봉사단원의 인도적 동기, 적극적 대인관계, 프로젝트에 대한 커미트먼트와 연관 지었다. 반면, 기술자문(technical advisors)에만 중점을 두는 개발프로젝트 봉사단원은 '냉담(distant)'하고 '무심(detached)'하게 보 이는 경향이 있었다(Lough \& Matthew, 2013:19).

케냐의 수원기관 직원은 다음과 같이 표현했다. “해외봉사단원은 우리와 함께 생활하면서 우리 의 어려움을 함께 느낌으로써 라포(rapport)를 형성하고 있다. 반면, 개발프로젝트를 담당하는 직 원은 자신이 최고인줄로 알며, 우리의 어려움을 문서상으로만 접근하고, 프로젝트 수행 후 보고서 만 작성한 채 결국 자신의 나라로 돌아가버린다(Lough \& Matthew, 2013:19).”

봉사단원과 수원기관 간 신뢰에 문제가 생기면 봉사단 활동과 성과도출에 차질이 생길 소지가 
증가하며, 수원국이 봉사단원과의 협력을 통해 누릴 수 있는 개발혜택도 그만큼 줄어들 수 있다. 이는 신뢰가 효과적인 봉사단사업 운영과 이행에 있어서 중요하며, 동시에 개발협력의 동력으로 써 중요하다는 점을 시사한다.

나) 프로젝트의 투명성과 책임성 증가

해외봉사를 통해 개발프로젝트의 투명성과 책임감이 증가할 수 있다는 점은 다양한 각도에서 흥미로운 주제이다. 첫째, 해외봉사단원은 큰 관료조직 및 정부 관료보다는 지역사회에 책임을 지 는 역할을 한다고 인식되며, 컨설턴트나 기술자문가(technical advisors)보다는 독립적 존재라고 보여진다(Keesbury, 2003; Lough \& Matthew, 2013:20에서 재인용). 예를 들어, 케냐의 관계 자들은 봉사단원들이 “정치적 색깔을 가지거나 특정 인물에 대해 영향력을 받지 않으며, 본인의 업무에 집중하면서 프로젝트를 진행해나간다”고 설명했다(Lough \& Matthew, 2013: 20).

둘째, 수혜기관 직원들은 해외봉사단원과의 상호작용을 통해 기관의 전반적 프로세스를 신중하 게 접근하고, 관리 및 기록(document)하는 법을 습득하게 되었다고 한다(Lough \& Matthew, 2013: 20). 이는 봉사단원이 성과/결과(results)를 기록하는 것의 중요성을 강조하였기 때문이라 고 볼 수 있으며, 이러한 습득은 중기적으로 프로젝트의 투명성과 책임성을 향상한다.

셋째, 봉사단을 수혜를 받는 기관은 외부 기관으로부터 재정지원을 받을 가능성이 상대적으로 높다고 보여진다(Lough \& Matthew, 2013:20). 그 이유는 해외봉사단원의 수혜를 받는 기관이 투명성과 책임도가 보다 높다고 지각되기 때문이다. 모두가 이러한 믿음을 가지고 있는 것은 아 니지만, 봉사단원이 활동하는 기관이 상대적으로 신뢰도가 높으며 따라서 재정의 기회도 증가한 다는 점은 흥미롭다.

다) 수혜기관의 명성과 존중 증가

몇몇 수혜기관은 기관의 명성과 존중이 해외봉사단원의 활동을 지원하면서 증가한다고 생각하 기도 한다(Lough \& Matthew, 2013:21). 지역사회 주민들은 해외봉사단원을 정기적으로 수용 하는 기관이 그렇지 않은 기관보다 더 평판이 좋다고 인식했으며, 현지직원 또한 '국제적 면모 (international face)'를 가진 조직이 타 조직에 비해 차별성 있다고 믿었다. 해외봉사단원이 '특 권이 있고 신분이 높다'고 보이기 때문에, 단원의 참여가 종종 조직에 전이되고, 이로써 '조직의 긍정적인 이미지'를 강화해준다(Lough \& Matthew, 2013:21).

그러나 조직의 명성과 존중이 높게 지각되는 효과는 해외봉사단원의 높은 전문성, 권한, 참여 
에만 국한되지 않고, 높은 특권과 권한을 보유한 개발협력 직원 혹은 '전문가'라면 누구에게나 적 용될 수 있다. 이러한 결과에 봉사활동이 큰 역할을 한다고 단정 지을 수는 없지만, 해외봉사단원 이 정기적으로 참여를 하는 기관일수록 자금지원을 받을 확률이 높다고 지각되는 것은 분명하다 (Lough \& Matthew, 2013:21).

라) 수원국에게 영감과 낙천관 부여

봉사단원은 지역사회 구성원과 조직의 직원에게 영감과 낙천성을 부여한다고 보고되는데, 과연 어떠한 경로를 통해 이 결과가 이루어지는지에 대해서는 불분명하다(Lough \& Matthew, 2013: 21). 특히 단기 봉사 단원에게서 낙천적 성향이 더 높다고 보고되는 경향이 있는데, 이는 새로운 문화 속에서 해외활동 경험에 대한 새로움, 참신함의 산물이라고 할 수 있다(Lough \& Matthew, 2013: 21). 물론 이러한 순수함(naïveté)의 이면에는 단점도 있겠지만, 수원국 직원들은 어려운 이슈와 문제로 고생하고 있는 수원국 작업 환경에서 해외봉사단원이 도덕성과 참신성을 고조시켜 준다고 보고했다(Lough \& Matthew, 2013:21). 특히 봉사단원이 보여주는 동기(motivation)에 있어서 그 커미트먼트와 에너지는 유급 노동자들과 질적으로 다르다고 현지직원들은 보고한다 (Lough \& Matthew, 2013:21). 이러한 점은 수원국측 직원들에게 큰 영감을 주고, 낙천적일 수 있도록 용기를 부여하고 있다.

상기 섹션에서 설명한 요소들은 봉사 특유의 단기 성과로써, 수원국 중심의 해외봉사사업 중장 기 성과 달성에 있어서 매개변수로 작용함과 동시에, 아래 명시할 중기성과 달성에 긍정적 상관 관계를 보인다고 할 수 있다.

\section{3) 수원국 측면의 중기적 성과: 서비스전달 및 자원확보}

가) 극빈층과 소외계층에게 공공서비스를 전달

수원국 측면의 중기적 성과로, 봉사활동을 통한 극빈층과 소외층으로의 공공서비스 제공이 있 다. 그 경로로는 첫째, 해외봉사단원은 지역사회에 공공서비스를 제공하는데 있어 중간자 역할을 해줌으로써 극빈층과 소외층에게 공공서비스를 도달하게 하는 효율적인 수단이 된다. 극빈층, 소 외층으로의 공공서비스 전달이 효율적이 되기 위해서는, 빈곤에 처한 당사자들이 무엇을 필요로 하고 있는지를 스스로 말할 수 있게끔 도와주어야 한다(Burns et al., 2015:21). 이를 위해 봉사 단원은 개발 프로그램에 극빈층과 소외계층 주민들이 적극적으로 참여할 수 있도록 이들에게 직 접 다가설 수 있다. 
둘째, 해외봉사단원은 지역사회에 존재하지 않는 서비스를 제공함으로써 지역사회에 부족한 자 원을 충당해준다. 예를 들어, 집밖으로 나가지 못하는 사람들을 보살피기, HIV/AIDS 감염자 가 정을 대상으로 보육 및 상담 지원 등의 활동을 통해 극빈층과 소외계층을 직접적으로 도울 수 있 다(Burns et al., 2015:20). 단, 봉사단원들의 활동이 수원국 내 유임금 직원들이 수행할 수 있 는 서비스를 대신함으로써 수원국 스스로 장기적 해결 방안을 마련하는 것을 뒷전으로 미루는 등 부작용이 발생할 수도 있기 때문에, 이를 방지하는 차원에서, 봉사단원의 활동이 유임금 직원들의 업무와 겹치지 않도록 신중히 검토한 후 지원해야 할 것이다(Burns et al., 2015:21).

\section{나) 자원의 확보}

봉사단원 활동이 수원국에 주는 중기적 성과 중 하나는 수원기관의 자원 확보이다. Lough \& Matthew (2013: 12)에 의하면 해외봉사단원의 자원을 끌어들이는 능력은 봉사단원으로부터 얻 는 혜택으로 가장 빈번히 명시된 요소이며, 여기서 말하는 자원(resource)은 봉사단원 개인의 자 금이나 기관이 자원봉사단 관계자로부터 간접적으로 받는 자금을 모두 포함한다.

Lough \& Matthew (2013:12)에 의하면, 자원 획득과 봉사활동의 연관성은 봉사단원이 선진 국에서 온 경우 더 강하게 보이는 경향이 있다. 또한 현지 직원은 해외봉사단원이 현지의 자원, 기술, 정보 기반 자원에 있어서 부족한 점을 메꾸어준다고 인식한다. 특히 커미트먼트가 높은 단 원의 경우 본인의 네트워크를 이용하거나 개인적 노력을 통하여 추가적 자금을 확보할 수 있으 며, 이로써 초기 투자가 몇 배로 불어날 수 있다. 예를 들어, 케냐의 한 수원기관의 경우, 해외봉 사단원이 조국으로 돌아가 현지 기관과 조국의 교회를 연계시켜주었고, 그 교회는 현지 기관에 매년 자금을 지원하게 된 사례가 있다(Lough \& Matthew, 2013:14).

주로 후원자들은 선진공여국으로부터의 개입이 없는 사업 및 기관에 대해 비관적이며 신뢰가 부족한데, 이는 소규모 단체나 저소득 지역사회가 자원을 효율적으로 관리하는 역량이 제한적이 라는 편견이 있기 때문이다. 이런 경우 봉사단원은 지역사회와 후원자 간의 가교 역할을 하여, 지 역사회의 자원과 원조의 순이익을 높이는 존재로 인식되는 편이다(Lough et al., 2013).

\section{다) 사회적 자본}

해외봉사활동을 통해서 얻는 사회적 자본은 수원국 측면에서 중기적 성과라고 볼 수 있다. 해 외봉사단원은 지역사회 주민과의 관계 형성을 통해서 지원 네트워크를 강화하고, 구체적인 협력 기회를 모색할 수 있다(Lough \& Matthew, 2013:15). 봉사단원 네트워크는 이들이 현지에 있 거나 본국으로 돌아갔을 때에도 자원에 대한 영향력을 가질 수 있다. 사회적 자본에는 자원 연계 
메커니즘(resource-bridging mechanism)도 포함되며, 물적자원 이외에 무형적 자원도 포함된 다. 구체적으로는 공공정책을 변화시키는 영향력, 선진국 $\mathrm{NGO}$ 와의 네트워크, 파트너기관과의 협 력을 위한 지역사회 동기부여 등이 그 예이다. 가끔, 해외봉사단원이 기존 조직 내 신뢰와 지역사 회의 유대관계를 약화시킨다는 반박이 제기되기도 한다. 그럼에도 불구하고, 해외봉사단원의 활 동이 지역사회의 사회적 지원, 통합, 결합과 연관이 있는 것은 분명하며, 다수의 선행연구는 해외 봉사가 지역사회 내 봉사활동의 결집과 현지 참여를 유도한다고 분석한다(Lough \& Matthew, 2013:15).

\section{4) 수원국 측면의 중기적 성과: 지역 역량 강화}

가) 지역에 영감부여 및 지역봉사 강화

해외봉사는 수원국 지역사회 내 봉사활동에 영감을 주고 지역봉사(local volunteering)를 강화 한다. 특히 Australian Red Cross (2014a:10)에 의하면, 봉사활동은 SDGs에서 강조하는 포함 성(inclusiveness) 달성을 위해 필수적이며, 그 이유는 해외봉사활동이 (1) 지역의 가장 취약한 주 민에게 필수 서비스를 제공해주며, (2) 지역주민이 자신의 잠재성을 최대한 발휘하여 생산적이며 창조적인 삶을 살아가도록 독려하기 때문이다. 특히, 다수의 수원국 단체는 해외봉사를 지역봉사 단원의 구성에 응용한다(Australian Red Cross, 2014a:11). 예를 들어, 몽골의 경우, 해외봉사 단원 선발에 있어서 현지 기관 및 지역조직과 함께 협력할 수 있는 단원을 선발함으로써, AVID 해외봉사단원을 몽골 자국 봉사단원의 역량강화에 활용하여 현지 봉사활동사업의 지속가능성을 향상한 바 있다. 이는 해외봉사단원에 대한 현지의 영감과 인식변화를 보여준다(Australian Red Cross, 2014a:11).

이 같은 변화는 무엇보다 수원국 내 봉사기관에서 지역봉사단원의 가치를 인식하게 되었다는 점에서 중요하며, 특히 적십자사와 같은 봉사단원 수원기관에서는 현지봉사단원을 모집, 관리, 감 독하고, 그들에게 권한을 부여함으로써 현지 봉사단의 역량과 효율성을 높일 수 있었다 (Australian Red Cross, 2014a:11). 봉사활동의 핵심은 지역사회 역량강화 및 지속가능개발이 다. 해외봉사단원은 봉사활동을 통해 수원국 지역주민들에게 지역봉사에 대한 영감을 주고 지역 봉사를 강화함으로써, 수원국 지역에 지속가능한 봉사활동 도모와 같은 혜택을 주는 것이다.

나) 현지 시민참여 촉진

Post-2015 개발의제는 시민참여의 중요성을 논의하고 있으며, UN 역시 평화와 정치참여를 제고하기 위해서 현지 시민의 개입을 우선순위로 두고 있고, 시민사회가 안정적인 관리체제와 기 
관의 효율성을 지원하는 데에 매우 중요한 역할을 담당함이 인정되고 있다(UN, 2013:16, 50; Lough \& Matthew, 2013:16에서 재인용). 시민의 참여(civic engagement)는 보다 넓은 시민 의 사회적, 정치적 공동체로의 참여를 뜻하며, 이는 해외봉사활동의 원칙에 내제된 의미 중 하나 이다(Australian Red Cross, 2014b:21). 봉사활동은 시민들이 직접 개발에 참여할 수 있는 중 요한 채널이다. 선진국 정부는 오랫동안 자발적 활동을 이끌기 위한 다양한 방식과 수단을 찾아 왔지만, 개도국의 경우 최근에서야 국가 정책적으로 개발의제 달성을 위한 자발적 활동에 시민참여 기회를 확대하기 위해 노력하고 있다. 봉사활동을 통한 시민참여는 통합(inclusion), 주인의식, 지속성뿐만 아니라 봉사사업 전달의 효과성과 책임을 강화한다. 특히 해외봉사활동은 현지시민의 참여를 도모하며, 시민참여와 시민사회의 견고한 결속력은 현대 경제의 효과적인 기능과 안정적 자유민주주의를 도모한다(Lough \& Matthew, 2013:16에서 재인용). 봉사단원의 박애정신과 자 기희생, 그리고 시민들의 사회기능 향상의 욕구가 시민참여의 중요한 동기이며, 해외봉사단원과 의 관계가 현지 시민들의 참여를 유도한다(Clary et al., 1998; Lough \& Matthew, 2013:16).

케냐의 현지 직원들은 해외봉사자와의 관계를 통해 단원들이 본국으로 돌아간 이후에도 현지의 사업에 대한 책임과 의무를 다할 수 있었다는 점에 감사와 헌신을 표하며, 해외봉사자들의 개입 이 직접적으로 시민참여와 현지의 국내봉사활동을 이끈 것을 이야기한다. 양국의 관계자 모두 해 외봉사자의 개입이 많은 활동일수록 현지 직원 및 현지봉사단원의 참여도가 더 높으며, 해외봉사 자들은 과거 개발활동에 참여해본 적이 없는 사람들을 자극하여 그들의 참여를 끌어낸다(Lough $\&$ Matthew, 2013:16). 해외봉사활동이 현지 봉사활동을 장려한다는 것은 앞으로의 연구 잠재 성이 더 많은 주제이다. 특히 Benjamin과 Lough(2012)의 연구에서는 해외봉사활동이 현지봉사 활동의 증진에 갖는 잠재적 효과를 강조한 바 있는데, 특히 케냐에서 해외봉사단원을 본 현지인 은 다음과 같이 말한 바 있다. "나라고 못할게 뭐가 있는가? 나는 아프리카 사람이다. 내가 왜 다 른 사람들을 도울 수 없겠는가? 만약 누군가가 우리를 돕기 위해 외국에서 왔다면, 나부터 시작 하면 안될까?” (Lough 2012:29; Australian Red Cross, 2014b:21에서 재인용)

$2011 \mathrm{UNV}$ 세계봉사활동보고서는 현지참여가 없는 봉사활동으로는 MDGs 달성이 힘들다는 내용을 담고 있다. 특히, UNV는 '지속가능한 개발과제 달성을 위해 정부가 자발적 자립과 상호원 조에 대한 현지 전통을 전략적으로 활용하고 이를 통해 봉사활동의 잠재적 성과를 발견할 수 있 도록 장려한다(UNV, 2011:93). 더 나아가 UNDP 역시 현지봉사활동을 MDGs 달성의 중요한 전략으로 수립한 바 있다(Australian Red Cross, 2014b:21).

다) 중기적 역량구축 및 기술 이전

역량구축은 기본적으로 관계를 중심으로 한 상호작용을 통한 기술과 지식의 공유를 말한다. 상 
호작용 및 관계형성은 역량개발의 중요 요소로 지적된 바 있으며, 봉사자단원과의 긴밀한 관계형 성은 봉사활동의 효과를 극대화시키는 요인이 될 수 있다(Lough, 2012). 케냐의 한 현지 직원은 해외봉사자와의 일대일 방식 훈련을 통해서 실질적인 기술(제안서 작성, 웹 디자인 등)을 점진적 으로 배울 수 있었는데, 특히 제안서 작성과 같은 어려운 기술을 배울 때에도 봉사자와의 돈독한 관계를 바탕으로 인내심을 가질 수 있었다고 말한다(Lough \& Matthew, 2013:14-15). 특히 봉 사단원과의 '경험을 통한 배움’이 쌓이면서 현지 청소년 및 현지 봉사 단원에게 미치는 해외봉사 단원의 영향력이 높이 평가된다. 한 현지 직원은 다음과 같이 말한다. "젊은 해외봉사단원은 현지 청소년과 잘 어울리면서 아이들에게 많은 영항을 끼칠 수 있었습니다. 특히 청소년들이 리더십을 기를 수 있도록 도움을 주었고, 아이들은 각자 다양한 재능을 개발할 수 있는 기회를 가지게 되 었습니다(Lough \& Matthew, 2013:14-15).”

제 I 장

제 II 장

섹

터

제 III 장

현지직원들의 경우, 봉사단원으로부터 새로운 기술을 있는 그대로 수용할 수 없을 때, '권한부 여(empowering)'라는 새로운 사고방식을 통해 역량을 기를 수 있었다. 봉사단원이 가르쳐준 기 술과 실습이 관련성이 낮거나 문화적으로 부적절한 경우에는 현지의 필요, 습관, 역량 등을 고려 하여 새롭게 조정할 필요가 있는데, 이러한 과정에서 권한을 부여받은 현지 직원들은 주인의식을 가지고 봉사단원 기여의 수용 범위와 대처방안을 생각하고 시너지 효과를 이끄는 역할을 담당한 다(Lough \& Matthew, 2013:14-15).

\section{5) 수원국 측면의 중기적 성과: 인식 변화}

가) 인권에 관한 인식

해외봉사사업을 통한 인권에 대한 인식개선은 수원국 측면의 중기적 성과라 할 수 있다. 이는 문화적인 규범이나 민족 또는 계급적 차별로 인해 소외된 사람들을 존중하는 다문화의 이해와 깊 이 연관되어 있다. Post-2015에는 인권이 중요한 영역으로 인식되고 있다. 많은 봉사단원은 훈 련과 워크숍, 그리고 다양한 사례와 모델을 통해서 여성, 원주민, 아동 등 약자에 대한 권리 향상 과 인종 평등 문제에 대한 인식을 개선하고 이들을 옹호하는 활동을 펼친다(Lough \& Matthew, 2013:20-21).

해외봉사단원을 통해 지역사회로부터 소외된 사람들을 향한 현지인들의 태도와 행동이 변화되 었다고 많은 현지 관계자들이 이야기한다. 예를 들어, 케냐 현지관계자는 한 일본 봉사단원의 포 용성과 인권존중을 목격하고 이를 통해 지역주민들은 편견에서 벗어나 서로 협력하며 평화롭게 지낼 수 있었다고 보고한 바 있다(Lough \& Matthew, 2013:20-21). 이러한 인식변화는 해외봉 사활동을 통한 갈등의 감소와 평화 증진의 가능성을 암시한다. 
나) 혁신과 진실성

봉사단원을 통해 흘러들어오는 다문화에 대한 이해, 다양성, 혁신, 진실성과 같은 긍정적인 영 향력은 개인뿐만 아니라 기관에 많은 기여를 한다. 우선 봉사단원이 현지 사람들과 지속적인 신 뢰를 쌓아 현지인들이 마음을 열고 기존과 다르게 생각하도록 돕는다. 또한, 해외봉사단원은 기관 내에서 정형화되지 않은 논의를 주도하는데 이는 조직문화의 개방성과 표현의 향상을 이끌며 기 관의 전문성을 강화한다. 예를 들어, 케냐로 파견된 봉사단원은 기관에서 후원금 마련방안으로 소 셜 미디어를 활용한 마케팅 개념과 아이디어 공유하고, 추후 기관에서 지역사회 프로그램으로 활 용할 수 있는 방안을 공유하였다(Lough \& Matthew, 2013:17-18).

이처럼 봉사단원의 아이디어는 지역주민들의 창조성과 역동성으로 발휘되지만 그 효과가 항상 긍정적인 것만은 아니다. 때로 예상치 못한 결과가 나타나거나 기관 간 불일치로 실현되지 못하는 경우도 있다. 예를 들어, 비관습적인 아이디어는 문화적으로 부적절하거나 실행 가능성이 적어서 관리에 문제가 발생하기도 한다. 또 다른 개발전문가(development practitioners)와 비교했을 때, 해외봉사단원의 혁신을 그다지 특별하지 않게 여길 수 있다(Lough \& Matthew, 2013:17-18). 그럼에도 불구하고 필요할 때에 새로운 아이디어가 적용된다는 점에서 봉사단원의 창조성이 갖는 효과는 점진적으로 인정되고 있다. 이는 봉사단원이 제한된 자원으로 개발 사업을 수행하면서 창 의적이고 독창적인 것을 만들어내고자 노력하기 때문이다. 대부분의 경우, 해외봉사단원은 제각 기 다양한 배경, 전문지식, 교육수준을 가지고 있기 때문에 현지에 광범위한 아이디어와 기술을 제공할 수 있다. 또한, 봉사단원은 기관 밖의 '외부인'으로서 더욱 신선하고 근원적이며 비관습적 인 창조성을 불어넣을 수 있다(Lough \& Matthew, 2013:17-18).

다) 개발에 관한 고정관념에 도전

혁신과 관련하여, 해외봉사활동은 개발에 관한 일반적 모델(prevailing models)에 도전한다 (Australian Red Cross, 2014a:17). 봉사단원과 수원기관의 관계는 선진국과 개도국 사이의 과 거 식민관계에서부터 비롯된다. 국제개발의 주요 목표인 '전 세계인의 삶의 질 향상'은 자연히 북 (선진국)이 남(개도국)에 제공하는 북(선진국)-남(개도국) 방향의 협력을 통해 달성되는 것으로 여 겨져 왔다. 한편, 해외봉사활동은 이러한 전통적인 인식에 맞서 새로운 시사점을 제시한다. 예를 들어, 호주의 AVID 프로그램은 상업화된 단기 해외파견 봉사의 기회는 주로 북쪽의 선진국 사람 들에게 주어지는 것'이라는 보편적인 관점과 다르게 운영된다. 즉, AVID 프로그램은 해외봉사단 원의 관심보다 수원기관의 필요를 우선시하여 수원기관에서 직접 해외봉사단원을 관리하고 지역 사회의 우선순위를 반영한 성과달성을 목표로 한다. 이러한 방식을 통해 수원기관은 전통적인 북 
-남 협력에 대한 의존도를 줄일 뿐만 아니라 자체 역량을 활용하여 지역사회를 개발할 수 있다.

흥미로운 점은, 해외봉사활동이 수원국 현지 사람들의 봉사활동 참여를 장려한다는 사실이다. 이는 앞서 거론한 현지 시민사회 참여 동원과 상통하는 효과이다. 해외봉사단원의 신뢰성과 협력으 로 인해 수원기관은 현지에서도 봉사단원을 모집하는데, 무엇보다 현지봉사단원은 지역사회 일원 으로서 더욱 적극적으로 봉사업무를 수행한다는 점에서 수원기관의 역량강화와 선진국에 대한 의 존도 감소에 영향을 미친다. 다시 말해, 해외봉사단원은 수원기관 내에서 특권적 위치(privileged position)를 차지하고 있지만 그럼에도 불구하고 해외봉사활동을 통해 수원기관은 더 많은 권한 을 부여받아 그들 스스로 기존의 개발 접근법에 대한 질문과 해결방법을 찾아갈 수 있게 되는 것 이다(Australian Red Cross, 2014a:17).

제 I 장

제 II 장

라) 봉사의 신뢰·가치에 대한 인식제고

해외봉사는 수원국 지역사회 내에서 봉사에 대한 신뢰와 가치를 더해준다. 몽골의 한 수원기관 은 해외봉사단원을 통해서 현지봉사단원에 대한 가치와 신뢰에 대해서도 사람들이 인정하기 시작 했으며, 봉사단원의 효율적인 모집과 협력 및 이들의 역량개발을 위한 다양한 방안을 모색할 수 있었다고 보고했다. 그 결과, 몽골 지역봉사단원들은 커리어개발 및 교육기회를 누리며 봉사단원 으로서 더욱 고차원적인 역할을 수행하고 단원의 활발한 참여도 이끌어낼 수 있었다고 한다 (Australian Red Cross, 2014a:11).

케냐에서는 해외봉사단원의 존재가 현지봉사단원이 자신의 가치를 높이 평가할 수 있게 만드는 계기가 되었을 뿐만 아니라 수원기관으로 새로운 지역봉사단원들을 모으는 효과도 가져왔다. 케 냐의 기관 관계자는 다음과 같은 이야기를 했다. "현지봉사단원은 해외봉사단원과 함께 일하고 훈 련받으면서 자신이 하는 일에 대한 가치를 높게 평가하게 되었습니다. 그들 스스로 지금 하는 일에 대한 의미를 찾고, 경력을 쌓으며 보람을 느끼고 있습니다(Australian Red Cross, 2014a:11).”

\section{6) 수원국 측면의 장기적 성과: 삶의 질 개선}

가) $\mathrm{UN}$ 새천년개발목표(MDGs) 및 웰빙에 기여

케냐의 봉사단원 수원기관 관계자들은 해외봉사파견의 장점으로 MDGs 기여를 세 번째로 많이 언급했다(Lough \& Matthew, 2013:15). 반면 페루의 단기 파견 봉사단원은 MDGs 기여의 중요 성에 대해서는 잘 언급하지 않았는데, 이는 해외봉사단의 기여에 대한 인지도에 있어서 국가 간 차이를 암시한다. MDGs 기여와 관련해서 페루는 주로 교육과 보건 분야 봉사단원의 기여를 거론 
했지만, 케냐는 오히려 성 평등과 여성의 인권과 관련한 활동에 대한 봉사단원의 기여를 언급했 다(Lough \& Matthew, 2013:15). 이처럼 봉사단원의 MDGs를 비롯한 교육, 보건, 인권과 같은 복지로의 기여에 대한 인식은 국가 및 기관의 목표와 파트너십 특성에 따라 다양하게 나타날 수 있다.

나) 문화 간 이해와 다양성

해외봉사단이 문화 간 이해와 다양성의 수용에 미치는 영향력은 적지 않다. 페루와 케냐의 참 가자들은 해외봉사단원과의 교류를 통해서 Mzungus(케냐 부족)와 Gringos(페루 부족)에 대한 인식이 크게 변화되었으며, 봉사사업에 대한 신뢰와 참여도도 높아졌음을 보고했다(Lough \& Matthew, 2013:16). 특히, 현지인들은 해외봉사단원이 기꺼이 현지문화를 배우고자 한다는 사 실을 중요하게 여겼다. 페루의 응답자들은 결속, 평화 그리고 다양한 사람들 간의 이해를 형성하 는 데에 해외봉사단원이 큰 영항을 끼친다고 보았고, 여기에서 문화 간 이해는 봉사자들의 페루 언어 구사 수준에 따라서도 좌우되었다. 문화 간 이해를 위해서는 새로운 개념과 아이디어, 관습 (practice)을 공유하려는 의지를 통해 쌓이는 신뢰가 중요하며, 지역사회 단위에서 효과적인 파트 너십을 이루는 전제조건이 된다.

해외봉사자들은 종종 역사, 민족, 인종, 계층 또는 지역사회 내 뿌리 깊은 편견에 대해 상대적 으로 인식이 낮은 덕분에 현지 소외계층이나 사회 차별 계층들과 잘 어울리는 경향이 있다. 예를 들어, 해외봉사단원은 케냐의 Kikuyu와 Luos, 또는 페루의 Mestizos와 Amerindians 같은 민 족이나 인종 모두를 똑같이 대함으로 부지불식간에 지역사회의 관용과 존경을 끌어낼 수 있다. 한 현지 직원은 페루는 인종차별이 심한 편인데, 다양한 국가로부터 해외봉사단원이 오면서 흑인, 백인, 그리고 황인까지 다양한 사람들을 만남을 통하여, 모든 사람이 같은 존재라는 것을 페루 현 지주민이 자연스럽게 깨달을 수 있었다고 보고했다(Lough \& Matthew, 2013:16-17). 케냐의 직원도 현지에 온 백인 봉사자들을 통해 지역사회의 뿌리 깊은 인종 차별이 점차 바뀌고 있다고 말했다. 봉사 프로그램이 처음 시작되었을 때만 해도 현지인들은 백인을 볼 때마다 매우 놀랐다. 그러나 봉사자들이 현지인들과 같은 음식을 먹고, 같은 공간에서 지내는 것을 보게 되면서 백인 들은 다르다는 인식이 점차 희미해지게 되었다(Lough \& Matthew, 2013:16-17).

흥미롭게도, 북 선진국의 봉사자들은 의도치 않게 포스트 식민주의와 인종 차별을 지속시킬 수 있다. 예를 들어, 인종에 대한 편견과 고집, 즉 서구 백인의 지식과 관습은 우월하다는 인식이 종 종 아프리카 흑인 봉사단원의 전문성을 상대적으로 낮게 평가하는 것으로 나타나는 경우도 있다 (Lough \& Matthew, 2013:17). 이러한 경향은 단순히 인종에 대한 편견인 '백인은 흑인보다 
많이 안다'는 것에 근거하고 있다. 그래서 남쪽 백인 봉사단원의 존재는 인종적 장벽을 허물기도 하지만, 의도치 않게 잘못된 허상을 강화하기도 한다. 더 나아가 북쪽의 지배와 패권 강화라는 포 스트 식민주의로도 이어질 수 있다. 그러나 모든 개발 및 원조 기관이 현지에 깊이 연관되지 않 았더라면 이와 유사한 시스템이 확산되거나 또는 더 심각한 수준으로 나타났을 것이라는 점도 지 적되고 있다(Lough \& Matthew, 2013:17).

\section{7) 수원국 측면의 장기적 성과: 기술 및 업무 차원}

가) 장기적인 기술 교환 또는 이전

해외봉사는 장기적인 기술 교환 또는 이전(exchange)이 가능하도록 기반을 마련해준다. 한 개

인으로부터 타인에게 기술이 전수되는 것을 일반적으로 '역량개발'이라 일컫는데, 예를 들어, 공여 국에서 파견된 해외봉사단원 또는 컨설턴트가 수원기관의 현지 직원에게 기술이나 지식을 가르쳐 주었다면 이는 곧 현지 직원의 역량개발이 이루어진 것으로 볼 수 있다. 수원기관과 해외봉사단 원 양쪽 모두 봉사사업의 성과로 '기술교환'을 우선순위에 두고 있으며, 최근 몇 년 사이 수원기관 역량개발의 일환으로 해외봉사사업 내 상호 기술교환이 강조되고 있는 추세이다(Australian Red Cross, 2014a:13).

수원국 중심의 기술교환은 다양한 측면에서 수원국에게 성과를 준다. 첫째, 기술교환은 수원기 관의 성과달성에 용이하다. 해외봉사단원과 수원기관 직원 사이의 기술교환은 봉사의 실질적 성 과를 끌어낸다. 예를 들어, 해외봉사단원이 활동한 케냐의 50 개 지역기관에서 회계 및 예산관리 역량이 강화된 것과 몽골의 국영 아동복지센터에서 상황대처능력 및 재난구조물품 공급시스템(창 고 설계 및 관리에 해외봉사단이 지원 등)이 향상된 것 모두 기술교환의 성공사례로 볼 수 있다 (Australian Red Cross, 2014a:13).

둘째, 수원기관은 새로운 정책과 새로운 업무처리방법 등을 이행할 수 있다. 수원기관은 해외 봉사단원의 업무를 관찰하며 새로운 정책과 접근법을 파악할 수 있고, 해외봉사단원은 수원기관 에서 직접 관찰하며 실질적인 필요를 파악하여 이를 반영한 다양한 접근법을 시도할 수 있다. 수원기관은 이 과정에서 구조적인 변화가 이루어지게 된다. 예를 들어, 몽골 수원기관 관계자는 다음과 같이 말한다. "과거에는 해외봉사단원과 함께 일할 때 기금확보 방안과 같은 예산 관련 업 무에만 집중하는 편이었으나, 어떤 봉사단원은 예산업무보다는 봉사단원 모집 및 아동보호정책 개선에 더 많은 시간을 쏟았고, 그런 노력 덕분에 기관의 관련 정책이 개선될 수 있었습니다. 또 한, 개선된 정책에 대해서 몽골어와 영어 버전으로 모두 발간할 수 있었고, 이러한 정책개선 노력 은 향후 기관의 후원금 마련 측면에서도 장기적으로 더 큰 의미를 가진다고 생각합니다 
(Australian Red Cross, 2014a:13).”

나) 업무 적절성 및 지속가능성 향상을 통한 봉사사업 질적 제고

봉사단원과 수원국 기관이 함께 업무에 몰입하면서 보내는 시간은 수원국 현지에 적합하고 (relevant) 지속가능한 개발이 가능하도록 만들어준다(Australian Red Cross, 2014a:15). 특히, 봉사활동 시간의 양적인 측면보다는 질적인 측면이 중요하다. 예를 들어 봉사단원이 주어진 기간 동안 현지 지역사회에 대한 이해도를 높이고, 지역 주민들과 긴밀한 관계를 형성하는 것이 봉사사 업의 성과 달성에 더 중요하다. 봉사단원은 현지인과 긴밀한 관계 유지를 위한 몰입시간을 활용하 여 수원기관의 필요를 파악하고, 자신의 역할과의 관련성을 높일 수 있다. 또한, 성과달성에 있어 서 지역사회의 자립능력과 지속가능성을 향상시키는 방식으로 봉사활동을 수행할 수 있다. 이러 한 업무 몰입을 통해 수원기관은 상품 개발에서부터 새로운 시스템 및 과정 도입, 근태문화까지 다양한 영역에서 성과를 달성할 수 있다.

케냐로 파견된 봉사단원은 현지 직원들이 해외봉사단원을 동료로 인식하기 시작하면 그때부터 단원을 대하는 태도가 완전히 달라짐을 지적하며, 단원이 '단순한 컨설턴트나 외부인이 아닌 우리 와 같이 일하는 동료이며, 언제든지 함께 아이디어를 공유할 수 있다는 생각을 가지고 동료로 인 식하게 된다'고 강조했다(Australian Red Cross, 2014a:15). 이는 즉, 봉사단원과 수원기관 사 이의 신뢰를 통해 새로운 업무방식이나 문제해결방안을 제안하거나 긍정적 태도를 조성하며 기관 의 변화를 끌어낼 수 있음을 암시한다. 반대로 수원기관도 몰입시간을 통해 봉사단원의 역할을 제대로 파악할 수 있다. 만약 수원기관에서 봉사단원의 역할을 잘 파악하지 못한다면, 단원에게 적합한 업무를 배정하지 못하며 주어진 인력을 제대로 활용하기 어려울 것이다. 해외봉사단원의 활동을 통해 긍정적인 성과를 보고한 기관의 경우, 수원기관과 단원이 실현 가능한 업무수행 계 획을 작성하고, 새로운 기회를 모색, 문제분석 및 해결방안을 검토하며 충분한 논의를 통해 역할 을 정했다는 사실을 발견할 수 있었다(Australian Red Cross, 2014a:15).

봉사활동이 자발적으로 사람 그리고 기관 간에 비전을 공유하고 상호 책임성과 호혜적 관계를 형성하는 것이라는 점을 고려한다면, 해외봉사단원은 수원기관의 목표달성을 지지하고 수원기관 중심에서 향후계획을 수립하는 것을 도와야 할 것이다. 이 같은 성과 달성을 위해서 봉사단원의 몰입시간이 중요함이 지속적으로 강조되고 있다(Australian Red Cross, 2014a: 15). 


\section{8) 파견국·파견기관(한국) 측면의 중기적 성과: 우정}

가) 관계형성

개발을 위한 봉사활동에 있어서 관계가 매우 중요하다. 특히 관계형성은 지역 사람들의 리더십 기술, 의사소통 기술, 인적관리 등을 포함한 소프트한 성과(soft outcomes)에 영향을 미치는 요 소이다(Burns et al., 2015:24).

봉사단원은 봉사활동의 효율성을 증가하고 동기를 부여하며 적극적으로 활동할 수 있도록 관계 형성에 의존하는 경향이 있다(Burns et al., 2015:27). 따라서 봉사활동은 개인적 활동이라기보 다는 사회적 활동이라 할 수 있다. 봉사단원들이 지역사회에 동화되는(embedding) 과정은 관계 의 구축과 네트워크의 발전에 중대한 영향을 끼친다. 해외봉사단원의 지역사회 내에서의 삶과 활

제 I 장

제 II 장 동(예: 지역사회 내에서 일어나는 축제에 참여하기, 마을 사람들의 집에서 저녁식사 함께 하기 등)은 봉사단원의 지역사회와의 관계를 증진하는데 기여할 수 있다(Burns et al., 2015:27).

이 가운데, 해외봉사활동에 대한 부정적인 인지도는 봉사단원에 대한 신뢰를 무너뜨릴 수 있으 며, 이는 봉사활동의 효과성을 크게 저해할 수 있다. 지역사회의 기대와 인지도는 지역사회나 조 직에서 봉사단원이 활동을 시작하기 전에 관리가 되어야 할 것이다. 또, 해외봉사단원을 '전문가' 로 홍보하는 것은 상호적 학습을 촉진하기보다는 일방적인 관계를 초래할 수 있다. 따라서 수원 기관은 봉사단원을 전문가로 포지셔닝하지 않는 동시에 봉사단원의 추가적 가치(added values) 에 대해 어필하는 방법을 찾아야 할 것이다. 여기에 충분한 언어적 역량의 부족은 쌍방향 관계에 장애가 될 수 있어서, 원활한 관계 형성을 위해서 봉사단원에게 언어 교육 강화가 강조되고 있다 (Burns et al., 2015:26).

나) 친밀성/우정/유대관계 형성

수원기관은 성공적 봉사활동 요소로서 비도구적 우정(non-instrumental friendship)을 중요 하게 고려하고 있으며, 특히 페루의 경우 이를 상위 3 번째 목표로 설정해놓은 바 있다(Lough \& Matthew, 2013:18). 기본적으로 친밀한 관계는 추가적인 혜택을 제공하지 않은 우정 및 사회적 지지와 관련이 있는데, 이는 도구적 가치의 사회적 자본과 구별된다. 현지 사람들은 봉사단원이 먼 곳까지 건너와서 지역사회와 함께 일하고, 개인적인 문제나 상황으로 어려움을 겪는 주민들을 돕는 모습을 보고 감동하여, 봉사단원과의 연결망과 우정을 쌓고 존경을 느끼게 된다(Lough \& Matthew, 2013:18-19).

예를 들어, 페루에서 가정부는 전형적으로 사회에서 차별받는 계층인데, 한 가정 고용인은 해 
외봉사단원과 교류하면서 자존감을 회복할 수 있었다고 전했다. 그 이유는, 해외봉사단원에 대해 '외국인은 우리보다 더 많은 것을 알고 있다라는 인식을 가지고 있기 때문에, 해외봉사단원이 가 정부와 가까운 친구처럼 이야기를 나눌 때, 이들의 자존감에 긍정적 영향을 끼칠 수 있었다고 보 고했다. 하지만 반대로 이러한 인식은 현지인들이 봉사단원과 자신을 비교하면서 현지인의 자존 감을 손상할 수 있는 여지가 있다는 점에서 위험하다.

그러나 현지 직원은 해외봉사단원과의 관계가 비교적 평등하며 다른 기술 지원자에 비해 더 특 별하다고 보고한다. 특히, 장기 봉사단원은 업무를 통해 기관 밖에서 직원 및 현지 주민들과 교류 할 시간이 많고 시간을 유연하게 활용할 수 있기 때문이다(Lough \& Matthew, 2013:19). 이러 한 유연성으로 인해 봉사단원은 온화함과 너그러움, 그리고 지역사회에 기여하고 싶은 열정과 신 뢰적 관계를 쌓고자 한다는 보편적인 인식이 존재한다. 현지 직원과 주민들은 기술 지원자와 달 리 이러한 관계가 매우 귀중하다는 것을 깨닫는다. 한 케냐 직원은 다음과 같이 말했다. "봉사단 원과의 유대관계는 현지직원의 역량을 강화할 뿐만 아니라 그들의 자존감과 전반적인 복지를 향 상시켰습니다. 친밀한 관계의 가치는 측정하기가 어렵지만 봉사단원과의 경험이 없었다면 우린 정말 많은 것을 놓쳤을 것이라는 점은 분명합니다(Lough \& Matthew, 2013:19).” 


\section{IV. 종합분석 및 결론}

아래 표는 상기 명시한 해외봉사 성과의 요소를 WFK 사업 성과모형의 3가지 측면 (봉사단원, 수원기관, 파견기관 측면) 및 Lough \& Matthew(2013:23)이 제시한 3가지 종류 (단기, 중기, 장기성과)의 틀에 입각하여 요약 및 재분류한 것이다.

〈표 10〉 해외봉사사업 성과의 요소와 분류

\begin{tabular}{|c|c|c|c|c|}
\hline 구분 & $\begin{array}{c}\text { 단기성과 } \\
\text { (added value) }\end{array}$ & $\begin{array}{l}\text { 중기성과 } \\
\text { (outcome) }\end{array}$ & $\begin{array}{l}\text { 장기성과 } \\
\text { (impact) }\end{array}$ & WFK 사업의 목표 \\
\hline $\begin{array}{l}\text { 단원 측면 } \\
\text { (개인) }\end{array}$ & & $\begin{array}{l}\text { 적극적 시민성과 } \\
\text { 사회적 자본 동원 }\end{array}$ & & $\begin{array}{l}\text { 봉사활동을 통한 } \\
\text { 자아실현 및 성장 }\end{array}$ \\
\hline \multirow{3}{*}{$\begin{array}{c}\text { 수원국 측면 } \\
\text { (개도국) }\end{array}$} & \multirow{3}{*}{$\begin{array}{l}\text { 해외봉사 특유 } \\
\text { 단기성과 } \\
\text { - 신뢰 } \\
\text { - 투명성, 책임성 } \\
\text { - 명성과 존중 } \\
\text { - 영감과 낙천관 }\end{array}$} & $\begin{array}{l}\text { 서비스/자원 차원 } \\
\text { - 소외층 서비스 전달 } \\
\text { - 자원의 확보 }\end{array}$ & $\begin{array}{l}\text { 삶의 질 차원 } \\
\text { - MDGs, 웰빙 } \\
\text { - 문화간 이해 }\end{array}$ & \multirow{3}{*}{$\begin{array}{l}\text { 개발도상국 주민들의 } \\
\text { 삶의 질 향상 }\end{array}$} \\
\hline & & $\begin{array}{l}\text { 지역 역량차원 } \\
\text { - 지역봉사 강화 } \\
\text { - 시민참여 } \\
\text { - 중기적 역량구축/기술이전 }\end{array}$ & \multirow{2}{*}{$\begin{array}{l}\text { 기술/업무 차원 } \\
\text { - 장기적 기술이전 } \\
\text { 기반 마련 } \\
\text { - 업무적절성 향상을 } \\
\text { 통한 봉사사업의 } \\
\text { 질적제고 }\end{array}$} & \\
\hline & & $\begin{array}{l}\text { 인식변화 차원 } \\
\text { - 인권의식 } \\
\text { - 혁신, 진실성 } \\
\text { - 기존 개발모델에 도전 } \\
\text { - 봉사에 대한 신뢰/가치 }\end{array}$ & & \\
\hline $\begin{array}{c}\text { 파견국 측면 } \\
\text { (한국) }\end{array}$ & & $\begin{array}{l}\text { - 우정 } \\
\text { - 관계 형성 }\end{array}$ & & $\begin{array}{c}\text { 개발도상국과 } \\
\text { 우리나라간의 우호협력 } \\
\text { 및 상호이해 증진 }\end{array}$ \\
\hline
\end{tabular}

출처: 저자 작성

이처럼 해외봉사단이 개발에 주는 성과의 분석 및 재분류를 통하여, WFK 성과지표 고도화 관 련 중장기 전략 수립에 대해 몇가지 제언을 도출할 수 있다.

첫째, WFK 사업의 향후 성과관리 지표는 위의 표에서 명시된 틀에서 성과요소 항목들을 분명 히 포함해야 할 것이다. 위 표에서 제시된 성과요소 분류의 틀과 항목은 기존에 성공적으로 실행된 다양한 현지조사연구, 인터뷰, 질적, 양적연구를 근거로 하여 제시된 모델이기 때문에 객관성과 활용도가 높다. 물론 위의 표가 현재까지 수행된 모든 해외봉사 관련 연구의 종합분석을 통하여 도출된 모델은 아니지만, 각 항목마다 공인된 연구의 근거가 존재함은 명백하다. 동 성과모델 틀을 
근거로 국제사회에 WFK 사업의 성과 틀과 지표를 제시한다면 WFK 사업의 성과를 보다 논리적 으로 설득하고 확산할 수 있고, 또 이를 통해 WFK 사업의 국제적 위상을 제고할 수 있을 것이다.

실질적 예로, 위의 모델을 반영함으로써 현재 WFK가 매년 실시하고 있는 만족도조사의 항목 개선이 이루어 질 수 있을 것이다. WFK 사업 만족도조사 결과보고서는 WFK가 봉사단원과 협력 기관을 대상으로 해마다 실시하는 설문조사로, 응답자 표본이 설문 문항에 응답하는 형식으로 자 료수집이 이루어진다. 사실상 현재 WFK 사업의 성과관리 조사에 가장 가까운 보고서이기 때문 에 잠재적 활용도가 높음에도 불구하고, 성과측정에 중요한 몇가지 설문문항을 포함하지 않고 있 다. 항목의 부재로 대표적인 것이, 위의 표에서 제시한 해외봉사단을 통한 수원국 인권의식 증진, 수원국 소외계층으로 봉사활동 서비스 전달, 수원국 기관의 명성과 존중 증가 등을 들 수 있다 (〈표 10〉참고). 동 성과 항목들은 수원국 측면의 단기 및 중기 성과이며, 동 항목들을 만족도조 사 설문에서 봉사단원 또는 수원국 기관 관계자를 대상으로 하는 질문으로 포함시켜 매년 그 측 정값을 비교 한다면, 향후 WFK 사업의 중기 성과를 평가하는데 객관적이며 공신력 있는 근거자 료가 될 수 있을 것이다.

둘째, WFK 중장기 성과평가 전략 수립에 있어서, 봉사단원이나 파견국(한국) 중심의 성과보다 는, 수원국을 중심으로 성과측정 지표가 다양하게 고안되어야 할 것이다. 위〈표 10〉에서 보다시 피, 대부분의 해외봉사에 관련된 최근 주요 해외문헌은 파견국이나 봉사단원 측면의 성과보다는 수원국 측면에서 보다 다양하며 심도있는 성과를 측정하는 추세이다. 이는 해외봉사사업이 파견 국이나 봉사단원에게 주는 성과나 혜택을 위한 것이 아닌, 개발성과 달성, 즉, 개도국의 삶의 질 향상에 그 본래 목적과 성과달성의 여지가 많다는 점을 암시한다. 물론, WFK 사업은 그 본래의 목표가 '개발도상국 주민들의 삶의 질 향상', '개발도상국과 우리나라간의 우호협력 및 상호이해 증진', '봉사활동을 통한 자아실현 및 성장’으로, 개도국, 우리나라, 봉사단원 측면 모두의 성과를 측정하는 것이 올바른 방향임은 사실이다. 그러나 WFK 사업이 개발 성과, 특히 SDGs 달성 등 에 기여하는 점에 대해서 보다 논리적이며 설득력 있는 근거를 축적하기 위해서는, 기존의 선행 연구와 증거가 풍부한 지표를 고안하는 것이 향후 $\mathrm{WFK}$ 중장기 전략수립에 도움이 될 것이다.

실질적인 예로 다시 WFK 사업 만족도조사를 들자면, 현재 만족도조사의 설문 항목에서도 '협 력기관 만족도'를 측정하는 문항보다는 '봉사단원 만족도'를 측정하는 문항이 더 양적으로 많고, 전체적인 문항 내용도 파견국이나 봉사단원에 더 집중하고 있는 것을 알 수 있다. 예를 들어, 〈표 $10>$ 에서 제시하다시피, 수원국 측면에서 '수원 기관의 명성과 존중 증가', '수원기관의 신뢰도 증 가' 등을 단기적 성과 설문문항에 추가하고, 더 나아가서 '문화간 이해 증진', '장기적 기술이전 기 반 마련' 등을 포함한 장기적 성과 지표를 설문문항에 추가하는 것만으로도, 향후 동 성과의 진척 을 모니터링 하는데 도움이 될 수 있을 것이다. 


\section{〈참고문헌〉}

이태주·박근혜·김헌·고은경·이순열·강하니·오연주·이선주·천유진·추빛나. 2016. "KOICA 해외봉사단사업 종합평가 최종보고서”. 서울: (사)글로벌발전연구원 주성수·조영호·이란희·김이경. 2014. "해외봉사단 효과성 증진을 위한 봉사단 분야별, 직종별 추진 전략” 서울: 한양대학교 제3섹터연구소

홍문숙·김헌·이순열·이선주·남종민·추빛나·이희철. 2016. "월드프렌즈사업 성과관리 지표개 발 연구”. 서울: (사)글로벌발전연구원

KOICA. 2016a. “해외봉사단과 국제개발협력”. 성남: 한국국제협력단(월드프렌즈교육원). (2016년 중 발간 예정)

2016b. “2015 월드프렌즈코리아 통합 만족도조사 결과보고서”. 성남: 한국국제 협력단

. 2011. “한국해외봉사단 20년 발자취”. 성남: 한국국제협력단 . 2010. “평가 및 성과중심관리 주요 용어사전”. 성남: 한국국제협력단

$\mathrm{KOICA} \& \mathrm{OECD}$. 2014. "개발활동의 평가: OECD 개발원조위원회(DAC)의 12 가지 교훈”. 성남: 한국국제협력단

Australian Government Department of Foreign Affairs and Trade. 2014. "Evaluation of the Australian Volunteers for International Development(AVID) program”. Canberra: Office of Development Effectiveness(ODE), Australian Government Department of Foreign Affairs and Trade

Australian Red Cross. 2014a. "International Volunteering: An investment in development (Summary report)". Melbourne: Australian Red Cross 2014b. "International Volunteering: An investment in development (Full Report)". Melbourne: Australian Red Cross

Burns, D., Picken, A., Hacker, E., Aked, J., Turner, K., Lewis, S., \& Franco, E. L. 2015. "The role of volunteering in sustainable development". London: VSO International \& IDS 
Devereux, P. 2008. "International volunteering for development and sustainability: Outdated paternalism or a radical response to globalisation?”. Development in Practice. 18(3):357-370

Franco, E.L. \& T. Shahrokh. 2012. "Valuing volunteering- Literature review”. London: IDS \& VSO

Haddock, M., \& Devereux, P. 2015. "Forum discussion paper 2015- Documenting the contribution of volunteering to the SDGs: The challenges and opportunities of universal SDGs". held during 4th-7th October, 2015, in Tokyo, Japan

Lough, B, J., Thomas, M., \& Asbill, M. A. 2015. "International Volunteering for Development: A desk review of Forum members' grey literature”. Illinois: University of Illinois at Urbana Champaign

Lough, B. \& Matthew, L., 2013. "Measuring and conveying the added value of international volunteering”. FORUM Discussion Paper. Illinois: University of Illinois at Urbana-Champaign

The International Forum for Volunteering in Development (FORUM). 2013. "The Paris accord on volunteering for sustainable development”. held in Paris during 27-30 October 2013, available at http://www.sif.org.sg/siv/uploads/ documents/resources/KO38A_The\%20Paris\%20Accord.pdf

UNV. 2015. "Sustainable Development Goals: Information and guidance for volunteer organizations”. Bonn: UNV

2011. "Assessing the contribution of volunteering to development: A participatory methodology". (Handbook for UN Volunteers, Programme Officers and Managers). Bonn: UNV Evaluation Unit 